\title{
Calibrating fluvial erosion laws and quantifying river response to faulting in Sardinia, Italy
}

\author{
J. Quye-Sawyer ${ }^{1}$, A. C. Whittaker ${ }^{1}$, G. G. Roberts $^{1}$ \\ ${ }^{1}$ Department of Earth Science and Engineering, Imperial College London, SW7 2AZ, UK. \\ Corresponding author: jennifer.quye-sawyer11@imperial.ac.uk.
}

\section{Highlights}

- Faults and transient rivers identified from digital elevation models

- New graphical approaches calibrate stream power erosional model

- Incision rate proportional to channel slope and square root of upstream area

- Throw rates of two normal faults predicted using inverse method

- Model predicts periods of Plio-Pleistocene activity for both faults

\section{Abstract}

2 It is now widely accepted that rivers modify their erosion rates in response to variable rock up-

3 lift rates, resulting in changes in channel slope that propagate upstream through time. Therefore,

4 present-day river morphology may contain a record of tectonic history. The simple stream power

5 incision model can, in principle, be used to quantify past uplift rates over a variety of spatial and tem-

6 poral scales. Nonetheless, the erosional model's exponents of area and slope ( $m$ and $n$ respectively)

7 and 'bedrock erodibility' $(k)$ remain poorly constrained. In this paper, we will use a geologically

8 and geomorphically well constrained Plio-Pleistocene volcanic landscape in central Sardinia, Italy,

9 to calibrate the stream power erosion equation and to investigate the slip rate of faults that have been

seismically quiescent in the historic past. By analysing digital elevation models, geological maps and 
Landsat imagery, we have identified the geomorphic expression of several volcanic features (eruption centres and basaltic lava flows) and three normal faults with 6 to $8 \mathrm{~km}$ fault traces within the outcrop. Downstream, river longitudinal profiles show a similar transient response to relative base level fall, probably as a result of relief inversion at the edge of the volcanic outcrop. From measurements of incision, local slope and upstream catchment area across eight different rivers, we calculate $n \approx 1, m=0.50 \pm 0.02$ and, using a landscape age from literature of $2.7 \mathrm{Ma}$, bedrock erodibility $k=0.10 \pm 0.04 \mathrm{~m}^{(1-2 m)} \mathrm{Myr}^{-1}$. There are also knickpoints on rivers upstream of two normal faults, and we used numerical inverse modelling of the longitudinal profiles to predict the slip rate of these faults since 2.7 Ma. The results from the inverse model show that the erosional parameter values derived in this study can produce theoretical longitudinal profiles that closely resemble observed river profiles upstream of the faults. The lowest misfit theoretical longitudinal profiles were generated by a model of temporally discontinuous footwall uplift with consistently low throw rates $\left(<0.1 \mathrm{~mm} \mathrm{yr}^{-1}\right)$. The predicted footwall uplift history is similar for the two faults, both showing periods of fault slip and no fault movement since $2.7 \mathrm{Ma}$.

\section{Keywords}

\section{Stream power}

Normal fault

Basalt

Sardinia 


\section{Introduction}

Earth's topography has evolved in response to geological and geomorphological processes over a range of spatial and temporal scales. Therefore, constraining the pace of landscape development should provide insights into the underlying geological forces that shape our planet's surface. Although it has long been recognised that river elevation is sensitive to changes in base level through time (e.g. Gilbert, 1876; Whipple and Tucker, 1999; Kirby and Whipple, 2001; Bishop et al., 2005; Whittaker et al., 2008), the calibration of fluvial erosion models that quantify elevation change over thousand to million year timescales remains an important challenge in geology. In this paper, we tackle this problem using rivers incising into dated lava flows on the island of Sardinia, Italy.

The erosion of rivers incising into bedrock with sparse alluvial cover ('detachment-limited' endmember erosion) is often modelled using the stream power equation,

$$
\frac{\partial z}{\partial t}=U-k A^{m}\left(\frac{\partial z}{\partial x}\right)^{n}
$$

where $\partial z / \partial t$ is the rate of change of channel elevation, $U$ is uplift rate relative to a given base level, $k$ is a measure of 'bedrock erodibility' that encompasses the effects of lithology, weathering, climate etc. on the rate of fluvial erosion, $A$ is upstream catchment area (as a proxy for discharge, channel width and other hydraulic variables) and $\partial z / \partial x$ is local channel slope (e.g. Howard, 1994; Whipple and Tucker, 1999; Whipple, 2004; Brocard and van der Beek, 2006; Attal et al., 2011). Although more complex incision models exist, incorporating other variables such as sediment supply, Equation 1 is useful to analyse rock uplift over geological timescales because relatively few types of observation are required. For example, catchment area and channel slope can be readily measured within the landscape from digital elevation data. In contrast, more complex models may require information that is not readily obtainable for the geologic past. 
For a river at equilibrium $(\partial z / \partial t=0)$, with uniform erodibility, Equation 1 predicts that chan-

nel slope will decrease downstream as a function of upstream area. However, rivers responding to a change in uplift rate exhibit breaks in slope, known as knickpoints and knickzones, that may propagate upstream over time (e.g. Kirby and Whipple, 2012). Knickpoints and knickzones are key geomorphic indicators of tectonic activity, and field observations alongside forward or inverse models of knickpoint migration have indicated the presence of possible active faults (e.g. Boulton and Whittaker, 2009; Pavano et al., 2016), revealed changes in fault slip rates (e.g. Commins et al., 2005; Whittaker et al., 2008; Whittaker and Walker, 2015; Kent et al., 2017; Staisch et al., 2018), estimated the temporal evolution of dynamic topography (e.g. Roberts and White, 2010; Miller et al., 2012; Roberts et al., 2012), and modelled vertical motions of large continental regions (e.g. Paul et al., 2014; Rudge et al., 2015).

Unfortunately, many of the stream power approaches developed to derive elevation change from topography are limited by unknown orographic coupling of precipitation and relief through geological time (e.g. Roe et al., 2002; Jeffery et al., 2013; D’Arcy and Whittaker, 2014), and spatial changes in erodibility between different lithologies in the same study area (e.g. Miller, 1991; Forte et al., 2016), which makes bedrock erodibility and hydraulic scaling difficult to quantify over geological time scales. Consequently, most studies presume that the parameters $m$ and $n$ are constants, with values often assumed to equal 0.5 and 1, respectively, in accordance with theoretical stream power considerations and observed present-day scaling between discharge, catchment area and channel width (e.g. Kirby and Whipple, 2001; Loget and Van Den Driessche, 2009; Hartley et al., 2011; Whittaker and Boulton, 2012; Ferrier et al., 2013; Fox et al., 2014; Beckers et al., 2015). Therefore, it would be highly desirable to constrain the parameters $k, m$ and $n$ of the stream power erosional equation in an area of broadly similar bedrock lithology and climate, and use this calibrated erosion model to 
estimate uplift rates in a different part of the landscape.

The Basaltic Plains of central Sardinia are a useful location to study the interaction of tectonics and fluvial erosion because the assumptions of the stream power erosional model can be tested in an area of spatially similar lithology and climate, and thousand to million year fault motion can be quantified solely from geomorphology. In this paper, we derive a new method to calibrate the stream power equation that explicitly tests the assumptions of constant parameter values, and use the calibrated erosional model for the Basaltic Plains to estimate fault throw rates in an area where faulting is poorly constrained by stratigraphy and historical seismicity.

\section{Study Area}

The present day geodynamic setting of Sardinia, and its existence as an island, results from the rollback of cold and dense subducting lithosphere that formed several western Mediterranean back-arc basins (e.g. Malinverno and Ryan, 1986; Lonergan and White, 1997). Palaeomagnetic data suggest that Sardinia rotated anticlockwise by approximately $30^{\circ}$ between 16 and $19 \mathrm{Ma}$ as a result of Ligurian-Provencal back-arc basin formation (e.g. Alvarez, 1972; Speranza et al., 2002; Carminati et al., 2012). Offshore reflection seismic data imply rifting that isolated Corsica and Sardinia from most of the Italian regions of Tuscany and Calabria began during the late Miocene (Mauffret et al., 1999). This rifting would evolve into spreading between Sardinia and Calabria at $\approx 7$ Ma (e.g. Carminati et al., 2012).

Onshore Sardinia, tectonic deformation created a series of Oligo-Miocene volcaniclastic basins in the west of the island (e.g. Faccenna et al., 2002). Calc-alkaline volcanism dates the initial terrestrial deposition in these basins to $32 \mathrm{Ma}$, and transgression to marine facies in the Burdigalian (dated to planktonic foraminifera zone N7) indicates that Sardinia began to subside during the early Miocene 

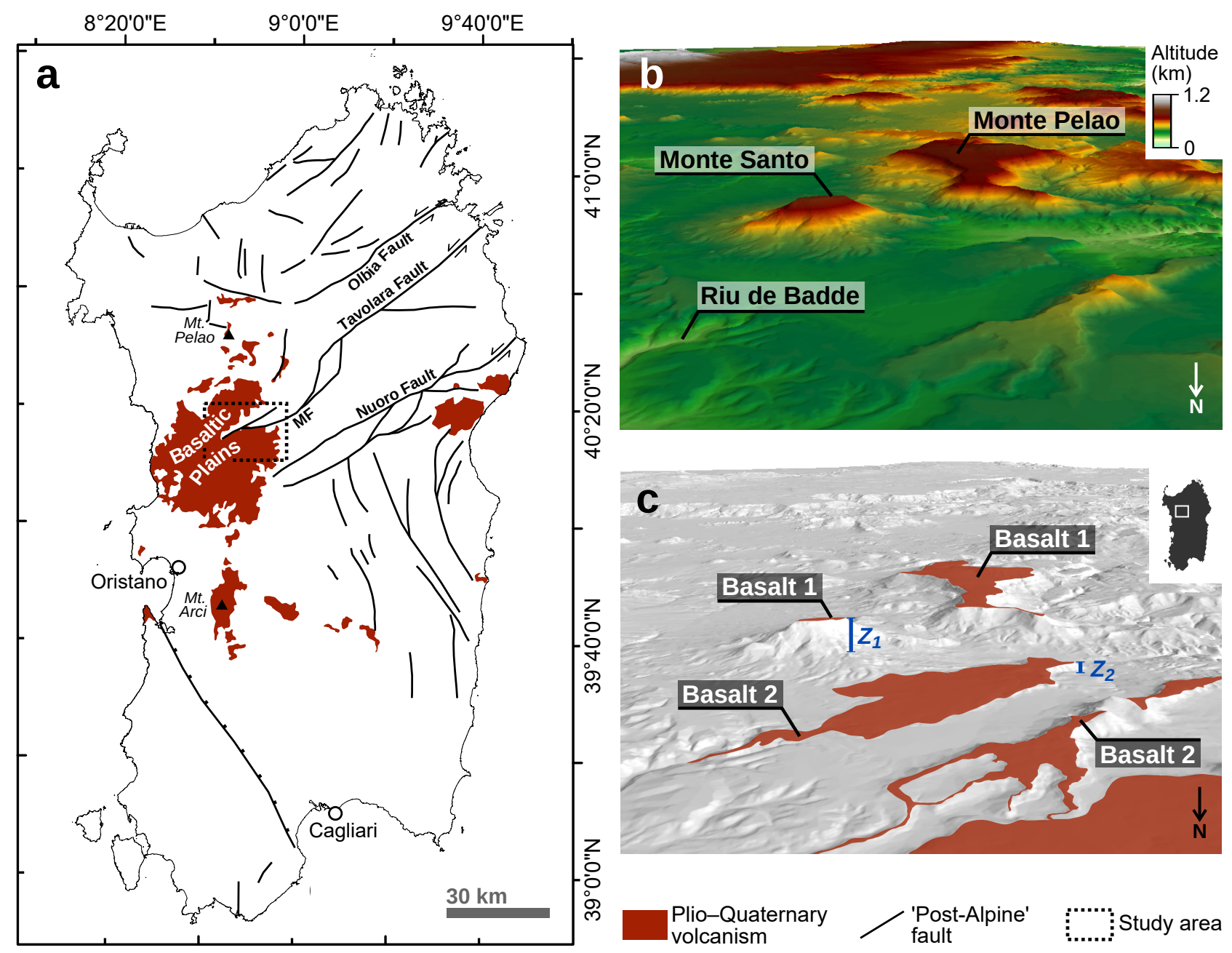

Figure 1: a) Map of Plio-Quaternary volcanic outcrops and faults on Sardinia adapted from Carmignani et al. (2015). Fault map and names from Pasci (1997). 'Post-Alpine' fault activity encompasses any possible movement after the end of Alpine compression / start of Apennine slab roll-back (approximately late Oligocene). MF = Marghine Fault. Ticks on hanging wall of normal fault. Black dashed box shows denotes area shown in Figures 2 and 3. Perspective view of b) topography from digital elevation model, and c) alkaline basalt outcrops (on topographic hillshade) in the vicinity of Monte Pelao. Basalt $1=$ Pliocene volcanism. Basalt $2=$ Pleistocene volcanism. Outcrop boundaries and basalt ages from 1:100,000 'Bonorva' geological map (Servizio dell'Attivià Mineraria, 1959) and Carmignani et al. (2015). $Z_{1}$ is the relative uplift of the basalt surface, compared to the sedimentary basin, since the eruption of Basalt $1 . Z_{2}$ is the relative uplift of the basalt surface, compared to the sedimentary basin, since the eruption of Basalt 2 .

(Andreucci et al., 2010). Reflection seismic data suggest that the Campidano graben (between Oristano and Cagliari) remained active into the Quaternary (Casula et al., 2001). The NE-SW trending fault arrays in the north east of Sardinia (e.g. Olbia, Tavolara and Nuoro faults), which previously created Eocene-Aquitanian transtensive basins, were probably also reactivated during the late Miocene opening of the Tyrrhenian Sea (Pasci, 1997; Helbing et al., 2006; Oggiano et al., 2009). 
Intra-plate volcanism, mainly of basaltic composition, dominates the Pliocene-Quaternary geologi-

cal record of the island (Beccaluva et al., 1977, 1989; Lustrino et al., 2000, 2007). The CampedaPlanargia Abbasanta-Pauliatino basaltic plains of Sardinia (hereafter 'Basaltic Plains') contain 850 $\mathrm{km}^{2}$ of non back-arc magmatism, up to $300 \mathrm{~m}$ thick, of predominantly hawaiite, mugearite, or basaltic andesite composition (e.g. Beccaluva et al., 1977; Lustrino et al., 2000; Andriani et al., 2001; Lustrino et al., 2004). These outcrops represent a series of late Pliocene-Early Pleistocene volcanic eruptions according to radiometric dating in Beccaluva et al. (1977) and Beccaluva et al. (1985). The lava flows were spatially superimposed on the Oligo-Miocene volcaniclastic back-arc basins that dominate the west of the island, and the Plio-Pleistocene volcanics intersect the Tavolara-Marghine fault system, suggesting that volcanism exploited this previously deformed crust (e.g. Beccaluva et al., 1977; Andriani et al., 2001; Faccenna et al., 2002; Lustrino et al., 2004, Figure 1).

Although Sardinia is generally considered to be currently tectonically inactive due to negligible historical seismicity (Angelone et al., 2005), deformation of last interglacial tidal notches and mapped faults within Late Pleistocene aeolian strata along the coast suggest that the Sardinia may have been tectonically 'active' during the late Quaternary (e.g. Mariani et al., 2009; Cocco et al., 2019). In addition, small normal faults are reported to offset the Basaltic Plains surface near the town of Macomer (e.g. Beccaluva et al., 1977, Figure 2), although their relationship with ongoing extension in the western Mediterranean region has not previously been analysed.

Throughout Sardinia, relief inversion is known to have played a key role in shaping topography of the volcanic regions (e.g. Funedda et al., 2000; Duncan et al., 2011; Deiana et al., 2015). To the north of the study area, we have identified volcanic units with dendritic outcrop patterns (Figure $1 \mathrm{~b}, \mathrm{c})$ that are similar to landforms seen in other volcanic provinces where lava flowed through valleys at the time 

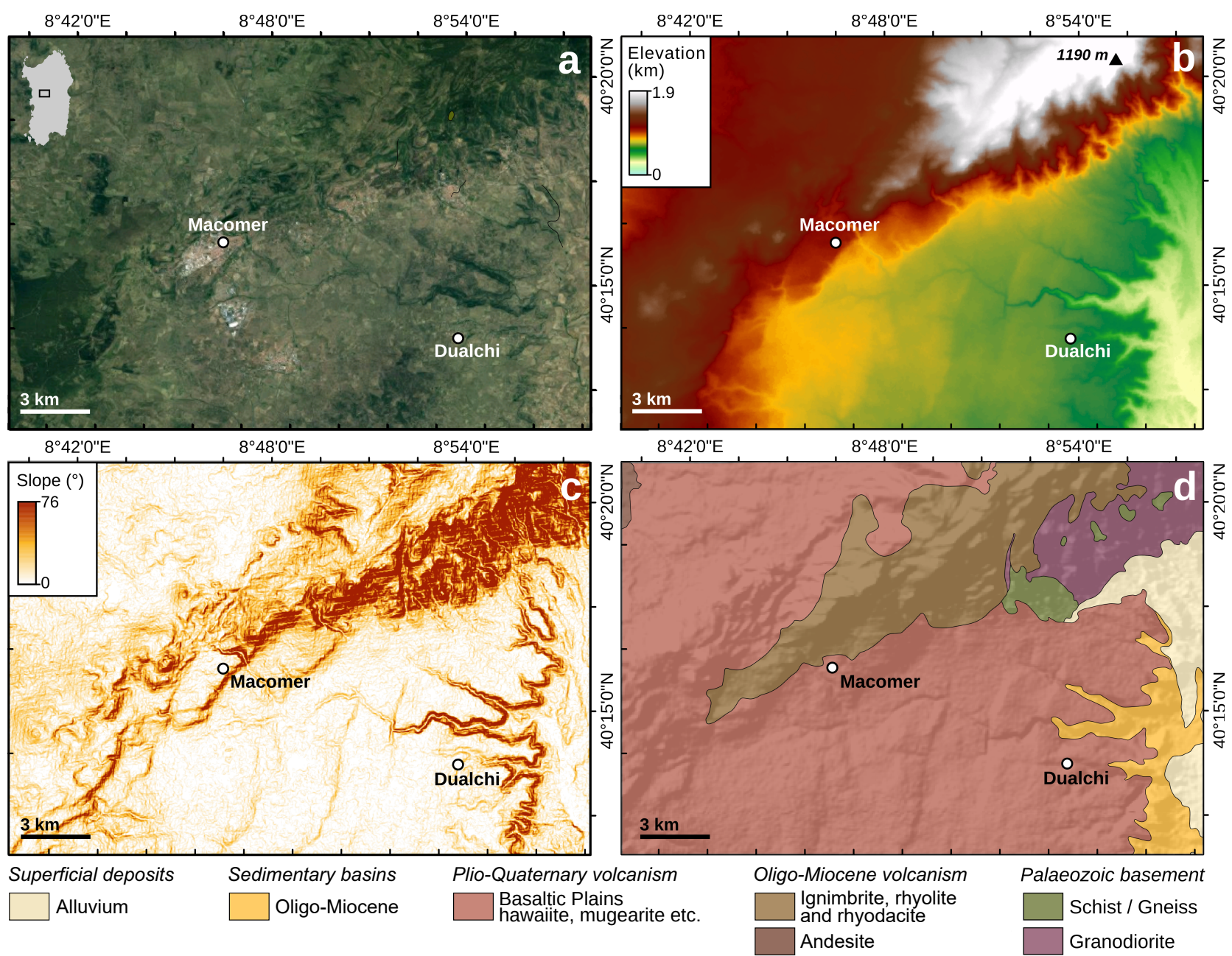

Figure 2: Data used to interpret geomorphology of the study area. a) Google Earth image. b) Topography from 1 arc second SRTM digital elevation model. c) Slope map derived from digital elevation model. d) Bedrock geology adapted from 1:100,000 'Macomer' map (Servizio dell'Attivià Mineraria, 1988) with topographic hillshade (key below).

of eruption (e.g. Ollier, 1982; Veldkamp et al., 2012). The volcanic outcrops reside at different elevations (Figure 1b,c), correlating strongly with outcrop age (Beccaluva et al., 1977), which suggests continual denudation of the surrounding basins. Based upon these observations, the increase in relief at the edge of the basaltic plateau in Figure 2 probably results from relief inversion between easily erodible basin strata and more resistant lithologies in the Basaltic Plains area (Funedda et al., 2000;

Duncan et al., 2011; Deiana et al., 2015). Therefore we hypothesise that relief inversion drives fluvial incision from the edge of the Plio-Pleistocene volcanic outcrop in the study area (Figure 2).

In addition to broadly similar outcrop lithology beneath the channels in the study area, which satellite 
imagery and aerial photography clearly show incising into bedrock with negligible alluvial cover, several climatic observations also suggest that the Basaltic Plains study area is suitable for river longitudinal profile analysis. First, there is no evidence for glaciation in western Sardinia during the last glacial period (Hughes and Woodward, 2017), so we assume that fluvial incision has been the dominant erosional process in the channels. Second, although changes in discharge can be difficult to determine on geological timescales because precipitation through time is usually not constrained with high temporal fidelity, river longitudinal profiles are generally insensitive to the high-frequency changes in precipitation that may occur between Quaternary glacial-interglacial cycles (e.g. Paul et al., 2014). In addition, a palaeoprecipitation study, based upon hypsodonty data, estimated that late Pliocene mean annual precipitation was 500-700 mm on Sardinia (Eronen et al., 2010), which is similar to the approximately $500-800 \mathrm{~mm}$ mean annual precipitation observed in the study area today, and suggests that Sardinia has experienced relatively stable rainfall patterns for approximately the last 3 Myr (e.g. Secci et al., 2010). This general temporal stability in precipitation means we can assume that precipitation leading to long term discharge, $Q$, has not changed significantly through time. Finally, we would not expect climate to spatially vary across drainage basins as the plateau in the study area is relatively small $\left(\sim 10^{2} \mathrm{~km}^{2}\right.$, Figure 2$)$.

\section{Methods}

We interpreted faults and volcanic eruption centres using satellite imagery, topography, the 1:100,000 scale geological map (Servizio dell'Attivià Mineraria, 1988), and topographic gradient derived from a digital elevation model (Figure 2). We assumed that all faults are relatively steeply dipping features exhibiting abrupt breaks in slope at the base of the fault scarp, and that eruption centres have approximately circular planform geometries and higher elevations than the surrounding outcrop (Melis et al., 2014) 
We used the Swath Profiler tool of Pérez-Peña et al. (2017) to find local relief along fault traces.

Low viscosity basaltic lava forms almost flat topography at the time of eruption (e.g. Karlstrom et al., 2018), so we assume there was no pre-existing relief between the footwall and hanging-wall prior to fault initiation. Furthermore, there are no significant hanging-wall sedimentary basins associated with these faults according to the geological map of Figure 2. Therefore, topographic relief across the unincised part of the fault trace should approximate cumulative fault throw.

We used the ArcMap hydrology toolbox to extract river profiles from the 1 arc second void-filled SRTM digital elevation model using methods described in Stucky de Quay et al. (2017). We assumed that the fluvial network is restricted to channels with an upstream area greater than $0.5 \mathrm{~km}^{2}$. This is a conservative threshold area estimate compared to field observations in low to moderate relief landscapes (e.g. Hancock and Evans, 2006; Orlandini et al., 2011), therefore it is highly unlikely that hillslope valleys will be incorporated into longitudinal profiles using this method. Nonetheless we only use rivers that can be confirmed using satellite imagery and published hydrology maps (Regione Autonoma della Sardegna, 2020).

\subsection{Calibration of stream power incision model}

The first objective of this paper is to evaluate the erosional parameters $n, m$ and $k$ of the stream power equation using river longitudinal profiles. Lithology and climate show negligible spatial or temporal variability in the study area (Section 2), so we may expect the erosional parameters $m, n$ and $k$ to be constant for all rivers draining the Basaltic Plains. In the study area, the total change in rock uplift at any longitudinal distance is the sum of channel elevation, $z$, and river incision, $I$. Therefore, Equation 1 can be expressed in terms of incision rate $(\partial I / \partial t)$ as

$$
\frac{\partial I}{\partial t}=k A^{m}\left(\frac{\partial z}{\partial x}\right)^{n} .
$$


The observations summarised in Section 2 imply that the $\sim 100 \mathrm{~m}$ difference in elevation between the Basaltic Plains plateau and the surrounding basin is likely to have gradually formed by a relief inversion process. The alternative hypothesis, that the $\sim 100 \mathrm{~m}$ difference in elevation between the plateau and the basin was created at the time of eruption (i.e. instantaneously in geologic terms), would require either one unfeasibly thick lava flow or multiple flows with thicknesses of a few metres to have repeatedly terminated in the same place without any topographic barrier. Since the latter scenarios are unlikely, we infer that the spatially consistent relief between the sedimentary basins and the eastern edge of the volcanic outcrop (Figure 2) results from a similar magnitude of relief inversion of the Basaltic Plains. Therefore, we assume that the relative uplift rate of rivers on the Basaltic Plains plateau compared to the Oligo-Miocene sedimentary basin, $U$, is spatially constant in the study area. In addition, thick soil development is rare on the Basaltic Plains today (e.g. Vingiani et al., 2004; Vacca et al., 2009), so we surmise that denudation caused by removal of soil should not have considerably changed the plateau surface. Therefore, the age of the Basaltic Plains landscape is equivalent to the age of the youngest phase of volcanism in the study area $(\approx 2.7 \pm 0.2 \mathrm{Ma}$, Beccaluva et al., 1977$)$.

We used the digital elevation model to measure incision (the difference between observed channel elevation and the elevation of the adjacent un-eroded Basaltic Plains plateau), $I$, upstream area, $A$, and local channel slope, $(\partial z / \partial x)$, from rivers with a range of catchment sizes. We did not make slope, area and incision measurements close to where a tributary joins the main stream as the sudden increase in discharge may significantly change channel slope within the distance $\mathrm{d} x$. We favoured measurements that were relatively far from the Basaltic Plains outcrop boundary (thick white dashed line on Figure 3). Near the outcrop boundary, the river channels have shallower gradients than further upstream, hence they are more likely to be alluviated and not fulfil the assumptions of the detachmentlimited stream power incision equation (Equation 1). At the outcrop boundary, valleys are $\sim 600 \mathrm{~m}$ 
wide and an accurate plateau elevation close to the channel cannot be guaranteed in these locations. We also only extracted data where the adjacent Basaltic Plains plateau did not show signs of local denudation.

Longitudinal channel gradients measured over large distances (e.g. $10^{2}-10^{3} \mathrm{~m}$ ) may not be representative of slope at a given catchment area because of the increase in discharge as a function of downstream distance. Moreover, in transient landscapes, the longitudinal distance used to evaluate local slope, $\mathrm{d} x$, should be as small as possible to only capture the parts of the channel network equilibriated to a particular uplift rate (e.g. Niemann et al., 2001). Unfortunately, channel gradients measured over small distances are likely to be sensitive to artefacts in the SRTM digital elevation model (e.g. Boulton and Stokes, 2018), and small scale lithological or fluid flow variability may control longitudinal profile shape at the shortest wavelengths (Roberts, 2019). To mitigate against these effects, we tested a range of moving window sizes and found that a 9 DEM pixel moving average of the channel elevation removed the small scale elevation 'steps' in the digital elevation model (supplementary Figure S1). We then calculated local channel slope over a longitudinal distance of $\leq 382 \mathrm{~m}$, as appropriate (supplementary Figure S1).

We used our measurements to evaluate stream power parameters $m, n$ and $k$ by minimising

$$
\left[\left(\frac{\partial I}{\partial t}\right) /\left(\frac{\partial z}{\partial x}\right)^{n}\right]-k A^{m}
$$

a re-arranged form of Equation 2, using a nonlinear least squares approach. If the erosional parameter values are constants, as hypothesised above, then measurements from different rivers should obey a power law on a plot of $(\partial I / \partial t) /(\partial z / \partial x)^{n}$ against area, $A$. We repeated our regression analysis with $n$ values in the range $0-2.5$ to investigate whether a linear or non-linear erosion law controls erosion rate. The most appropriate values of $m, n$ and $k$ should produce the smallest residuals between the 
observations and the best fit regression line.

We assume that, where measured, local channel slope has adjusted to the time-averaged incision since $2.7 \mathrm{Ma}$ and our nonlinear regression allows us to evaluate this assumption. This analysis also assumes that the catchment platform geometry has been fixed since 2.7 Ma. However, we recognise that it takes time for drainage patterns to develop and this assumption may not be appropriate for the entire duration of fluvial incision, especially during the nascent stages.

We estimated uncertainties in $m$ and $k$ using a bootstrap technique. We repeated the least squares fit after adding normally distributed random noise to the $\partial z / \partial x$ and $\partial I / \partial t$ measurements. Although our 9 pixel moving average of channel elevation corrects for random elevation error to some extent, we added $\sim 1 \mathrm{~m}$ of noise to $\partial I / \partial t$ to account for other uncertainties in the SRTM data (e.g. Akgul et al., 2017; Becek et al., 2019), with an additional $1 \mathrm{~m}$ uncertainty in plateau elevation (from the $\sim 1 \mathrm{~m}$ one standard error of elevation in a 5 DEM pixel radius, calculated using Focal Statistics in Arc Map). The added noise for the channel slope measurement, $\partial z / \partial x$, was based upon the local variability in measured channel slope at each location. After 3000 iterations of the bootstrap procedure, we used the normal distribution of all best fit parameters to estimate the standard error of $k$ and $m$. We subsequently repeated our analysis to account for the 0.2 Myr uncertainty in landscape age.

The stream power equation can also be linearised by calculating the logarithm of each term, which is often used for techniques such as slope-area analysis to estimate concavity $(\mathrm{m} / \mathrm{n})$ or channel steepness (e.g. Sklar and Dietrich; Kirby and Whipple, 2001; Wang et al., 2017). Therefore, we would like to investigate the whether employing least squares techniques on a linearised form of the steam power equation would change our results. Detailed methods for this additional analysis are presented in supplementary information. 


\subsection{Numerical inverse modelling of longitudinal profiles}

The 'best-fit' erosional parameters were used to analyse fault-related uplift through numerical inverse modelling of longitudinal profiles. Longitudinal profile inversion approaches aim to produce an uplift rate history that is consistent with the observed river elevation (e.g. Pritchard et al., 2009; Roberts and White, 2010; Goren et al., 2014; Glotzbach, 2015). To find this uplift rate history, the inverse model produces theoretical river profiles using a calibrated stream power equation (Equation 1).

To apply this method to the Basaltic Plains study area, we assume that incised regions of the volcanic plateau upstream of faults have formed as a result of relative uplift of the fault footwall. Observations and models demonstrate that deformation perpendicular to fault strike is finite in space, and the distance over which uplift occurs depends on fault length and the elastic thickness of the footwall (e.g. Gupta and Scholz, 1998; Ebinger et al., 1999). However, if the wave of incision has not propagated far from the fault trace, and if fault blocks are not significantly tilted, as seems to be the case for this study area, then we can assume that footwall uplift perpendicular to the fault trace is a function of time only. Accordingly, we employed the one dimensional inverse approach outlined in Roberts and White (2010).

The inverse method of Roberts and White (2010) produces a model of rock uplift rate as a function of time, calculates the theoretical longitudinal profile associated with this uplift history according to the stream power equation using a Crank-Nicolson and upwind differencing scheme, and evaluates the trial function, $H$. These steps are repeated until the trial function, $H$, is minimised. Subsequent uplift models are designated according to Powell's algorithm, which uses a conjugate gradient method to find the global minima of the trial function. The trial function, $H$, is 


$$
\begin{array}{r}
H=\sqrt{\frac{1}{N} \sum_{i=1}^{N}\left(\frac{z_{i}^{o}-z_{i}^{c}}{\sigma_{i}}\right)^{2}}+w\left\{\sqrt{\frac{1}{M-1} \sum_{k=2}^{M}\left(\frac{\partial U_{k}}{\partial t}\right)^{2}}+\frac{1}{M} \sum_{k=1}^{M}\left(\frac{\partial^{2} U_{k}}{\partial t^{2}}\right)\right\} \\
+\frac{p}{M} \sum_{k=1}^{M}\left(\cosh U_{k}-1\right)
\end{array}
$$

where $z_{i}^{o}$ is the observed elevation at upstream distance $i, z_{i}^{c}$ is the elevation at the same distance predicted by the inverse model, $\sigma_{i}$ is the observation uncertainty (the vertical error in the SRTM digital elevation model), $N$ is the total number of elevation measurements along the river, $M$ is the number of timesteps in the model output, $U_{k}$ is predicted uplift rate at timestep $k$, and $w$ and $p$ are positive constants. The first term on the right hand side of Equation 4 is the root-mean-squared (rms) misfit (or error), which tends towards zero as the theoretical longitudinal profile more closely resembles the observed profile. Equation 4 reveals that the rms misfit will be less than 1 if the average predicted elevation matches the average observed elevation within error. The next two terms in Equation 4 define the temporal smoothness, and the final term is a positivity constraint, which penalises the model if it generates negative uplift rates. The inverse method assumes that $H$ is minimised when the change in $H$ between subsequent inversions is less than $10^{-4}$.

For this analysis, we used 27 timesteps which, for a total model run time of $2.7 \mathrm{Ma}$, results in a $100 \mathrm{kyr}$ temporal resolution. The inverse model may linearly interpolate between these timesteps to ensure numerical stability according to the Courant-Friedrichs-Lewy condition (Roberts and White, 2010).

The damping parameter, $w$, of Equation 4 was fixed at $10^{-4}$, two orders of magnitude smaller than the value used in Roberts and White (2010), to allow the model to produce sudden changes in fault slip rate if necessary. The positivity parameter, $p$, was fixed at 1.0 to prevent negative uplift rates. The 


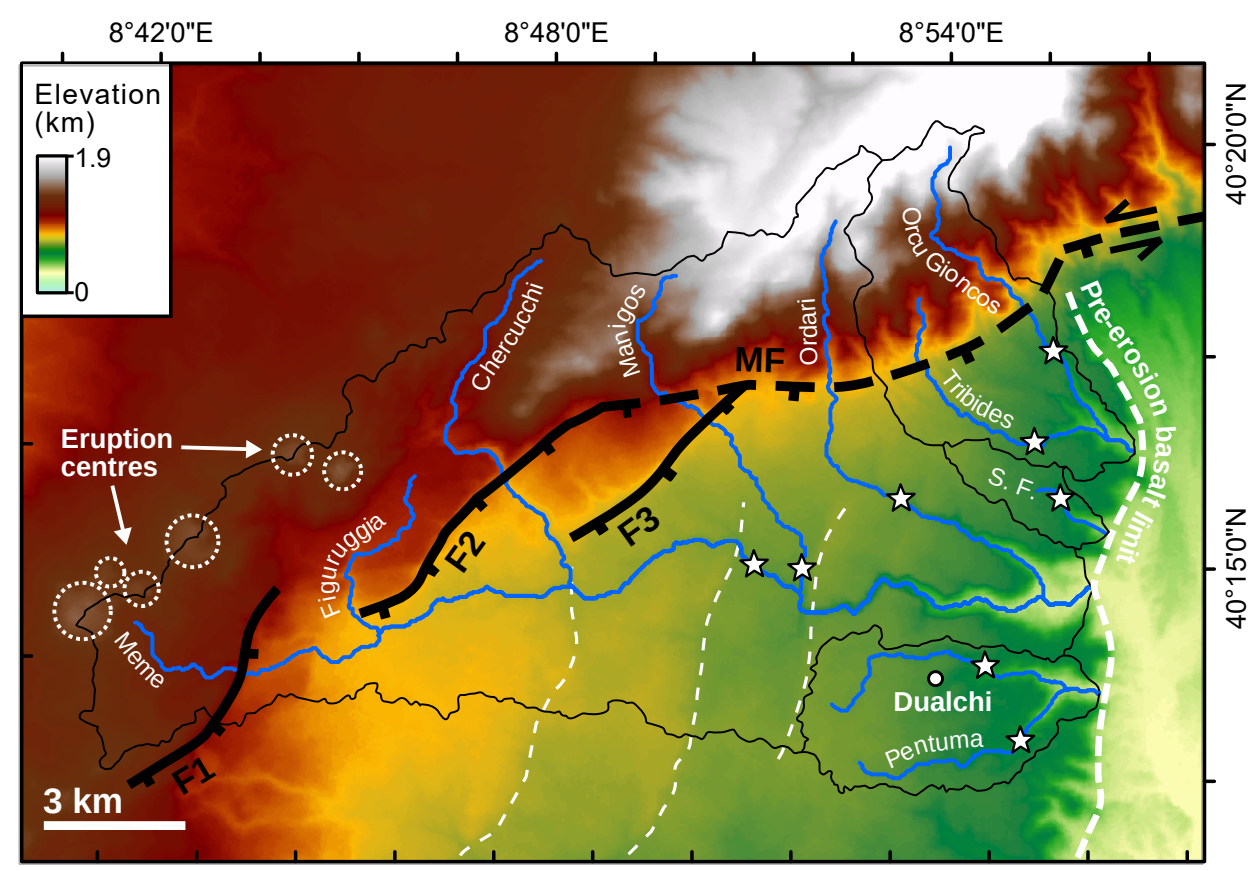

Figure 3: Interpreted geology and geomorphology of the study area. Thin white dashed lines = inferred boundaries of individual lava flows. Thick white dashed line = Interpreted Basaltic Plains outcrop boundary prior to fluvial incision. F1-3 = normal faults, and MF = Marghine Fault (ticks on hanging wall). Blue lines represent rivers extracted from SRTM digital elevation model. SF $=\mathrm{Su}$ Fruscu river. Stars denote upstream extent of fluvial incision from Basaltic Plains outcrop boundary.

starting profile (i.e. the assumed topography at $2.7 \mathrm{Ma}$ ) resembled the dip of the unincised plateau surface adjacent to the faults.

\section{Results}

\subsection{Interpretation of geology and geomorphology}

We have identified three faults in the western section of the Tavolara-Marghine fault system that lie entirely within the Basaltic Plains outcrop (F1, F2 and F3 in Figure 3). These faults have 6-8 km long fault traces, and strike NE-SW or NNE-SSW, in agreement with the structures described by Beccaluva et al. (1977). In light of their consistently steep $\left(>10^{\circ}\right)$ fault scarps, which abruptly flatten without the presence of an anticline on the western side of the fault traces, we consider these structures to be normal faults, as suggested by Beccaluva et al. (1977). Although the regionally-mapped 
Marghine Fault has the largest change in elevation and slope in the study area (Figures 2 and 3), it does not noticeably offset the basaltic plateau surface at the resolution of the available data, so we cannot deduce if this structure has been active since the onset of volcanism.

Local relief of faults F1-F3 was calculated using maximum and minimum elevation in a $200 \mathrm{~m}$ swath, an appropriate distance to measure plateau elevations in footwall and hanging wall. Figure 4 shows that relief along the fault trace increases towards the centre of faults F1 and F3, reaching a maximum relief of $60 \mathrm{~m}$ and $50 \mathrm{~m}$, respectively. However, relief remains at a maximum as fault F2 intersects the Marghine Fault. Fluvial erosion has clearly incised the footwalls of these three faults, though this is less pronounced in the hanging walls (Figure 4), which suggests that the rivers are increasing their erosion rates as a response to relative uplift caused by long term fault slip.

We interpret several volcanic eruption centres within the Plio-Pleistocene volcanic lithologies, all of which lie in the footwalls of the normal faults and to the southwest of the Marghine Fault (dashed white circles in Figure 3). The geographic location of these eruption centres implies that lava flows will be thickest in the west of the study area, and may partially explain the increase in elevation of the basaltic plateau surface towards this region. The main drainage divide intersects these possible eruption centres (Figure 3), which suggests that the current river planform geometry has developed in response to the topographic disruption caused by volcanism. The thin white dashed lines in Figure 3 denote continuous breaks in slope within the basalt. These features do not have the same orientation as the normal faults, and are approximately parallel to the extrapolated pre-erosion outcrop boundary (thick white dashed line in Figure 3), so possibly represent the edges of individual lava flows.

All river longitudinal profiles have steeper channel slopes within the incised sections of the river, and incision reaches further upstream in larger catchments (Figure 5). In addition to the change in slope 
between incised and unincised bedrock in the downstream sections of the longitudinal profiles, there are several breaks in slope further upstream on the Meme and Chercucchi profiles that may represent knickpoints (Figure 5). Figure 6 shows the sections of these longitudinal profiles that are upstream of the fault traces. Some breaks in slope on the Chercucchi appear to spatially correlate with boundaries within the Oligo-Miocene volcanic lithologies or relief that formed at the time of Plio-Quaternary volcanic eruptions (e.g. $2500 \mathrm{~m}$ and $5500 \mathrm{~m}$ upstream of the fault trace on Figure 6a). These apparent knickpoints may have arisen from erodibility contrasts between different lithologies (e.g. rhyolite and pumice). In addition, some breaks in slope on the Meme river lie on unincised Plio-Quaternary volcanic lithologies (e.g. $2500 \mathrm{~m}$ upstream of the fault on Figure 6b); these changes in channel elevation probably represent relief of pre-eroded topography. However, there are also prominent knickpoints, one on each river, that lie within the Basaltic Plains outcrop and are not associated with breaks in slope outside of the valley (circles on in Figure $6 \mathrm{c}, \mathrm{d}$ ). These prominent knickpoints are approximately $500 \mathrm{~m}$ and $1500 \mathrm{~m}$ upstream of their respective faults, and mark the upstream limit of the fluvial incision from the fault trace (white circles of Figure 6). Since there is negligible incision directly downstream of the faults, we suggest that these prominent knickpoints could only have formed at, or upstream of, the fault traces. There are also other breaks in slope within the incised profiles (black circles of Figure 6). Fluvial inverse modelling will investigate whether these breaks in slope are knickpoints created by changes in fault throw rate.

There may be a small knickpoint upstream of fault F3 on the Manigos river (Figure 5a). However, fault F3 is close to the Marghine Fault at this location, so we cannot unequivocally deduce if vertical motions of fault F3 or the Marghine Fault caused the deformation apparent in the Manigos longitudinal profile. The Figuruggia river also incises into the bedrock as it crosses the relay ramp structure between faults F1 and F2 (Figure 2), and its longitudinal profile shows a corresponding change in slope at this location (Figure 5). Therefore, we infer that the planform geometry of the Figuruggia 


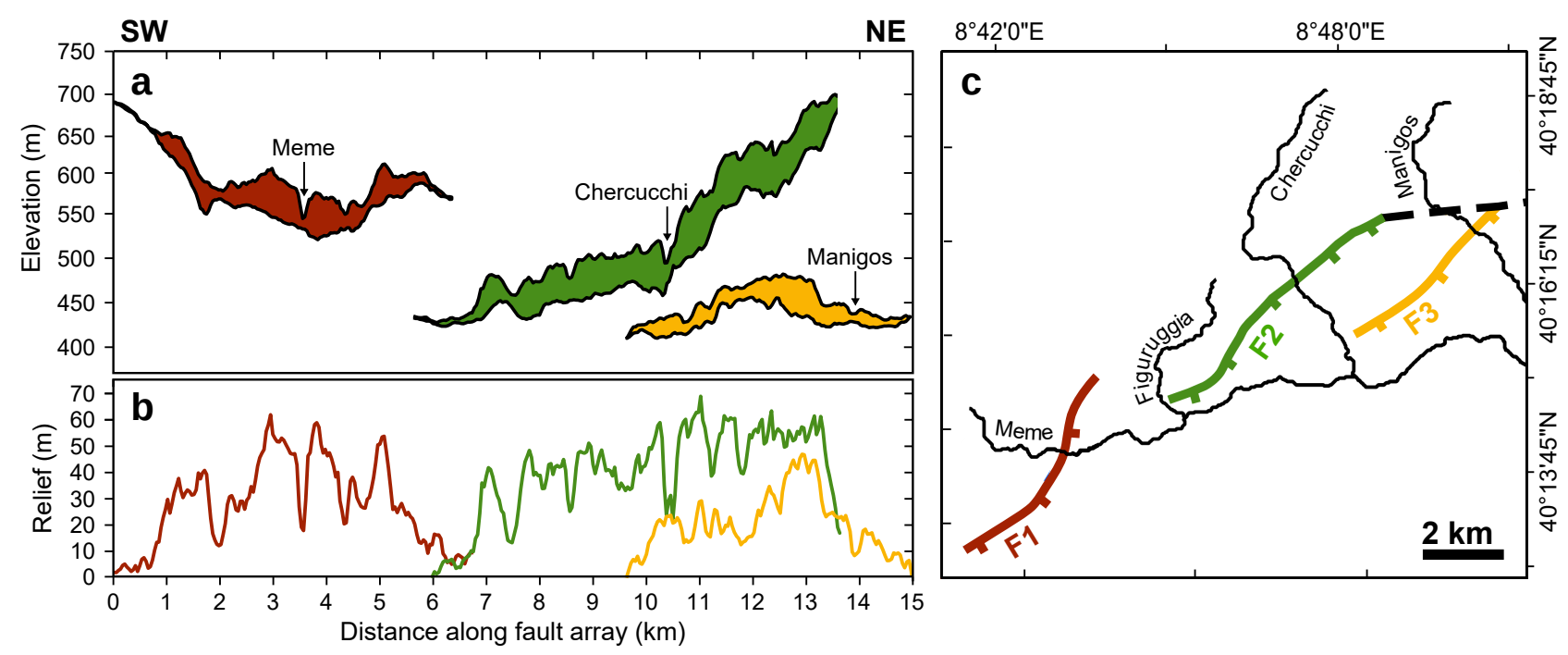

Figure 4: Topographic relief for normal faults in the study area. a) Maximum and minimum elevations, from sea level, along fault traces in $200 \mathrm{~m}$ swath. Faults F1-F3 shown relative to their approximate south-north positions along fault array. b) Difference between maximum and minimum elevation in a $200 \mathrm{~m}$ swath. Colours for elevation and relief correspond to colours for fault traces on panel (c). c) Fault traces and rivers in the west of the study area. Marghine Fault shown as dashed line.

river formed in response to fault activity, which has created a local topographic high in the footwall of fault F2 and a topographic low in the hanging wall of fault F1. We surmise that the knickpoint on the Figuruggia river also originates from fault-related deformation.

No consistent knickpoints are found on the Ordari, Orcu Gioncos or Tribides rivers upstream of the Marghine Fault (Figure 5). The absence of a consistent set of knickpoints would imply that the Marghine Fault has not experienced a change in throw rate during the time that an erosive wave would propagate from the fault trace to the river head.

\subsection{Stream power incision model parameters}

Using the criteria in Section 3.1, we measured channel slope, fluvial incision and upstream area at twelve locations over eight rivers (Figure 5 and Table S1, supplementary information), including all rivers in Figure 3 and the Mu Putzu river, which flows southwards from its headwaters close to the Pentuma watershed. The considerations in section 3.1 limit the number of measurements that can be 

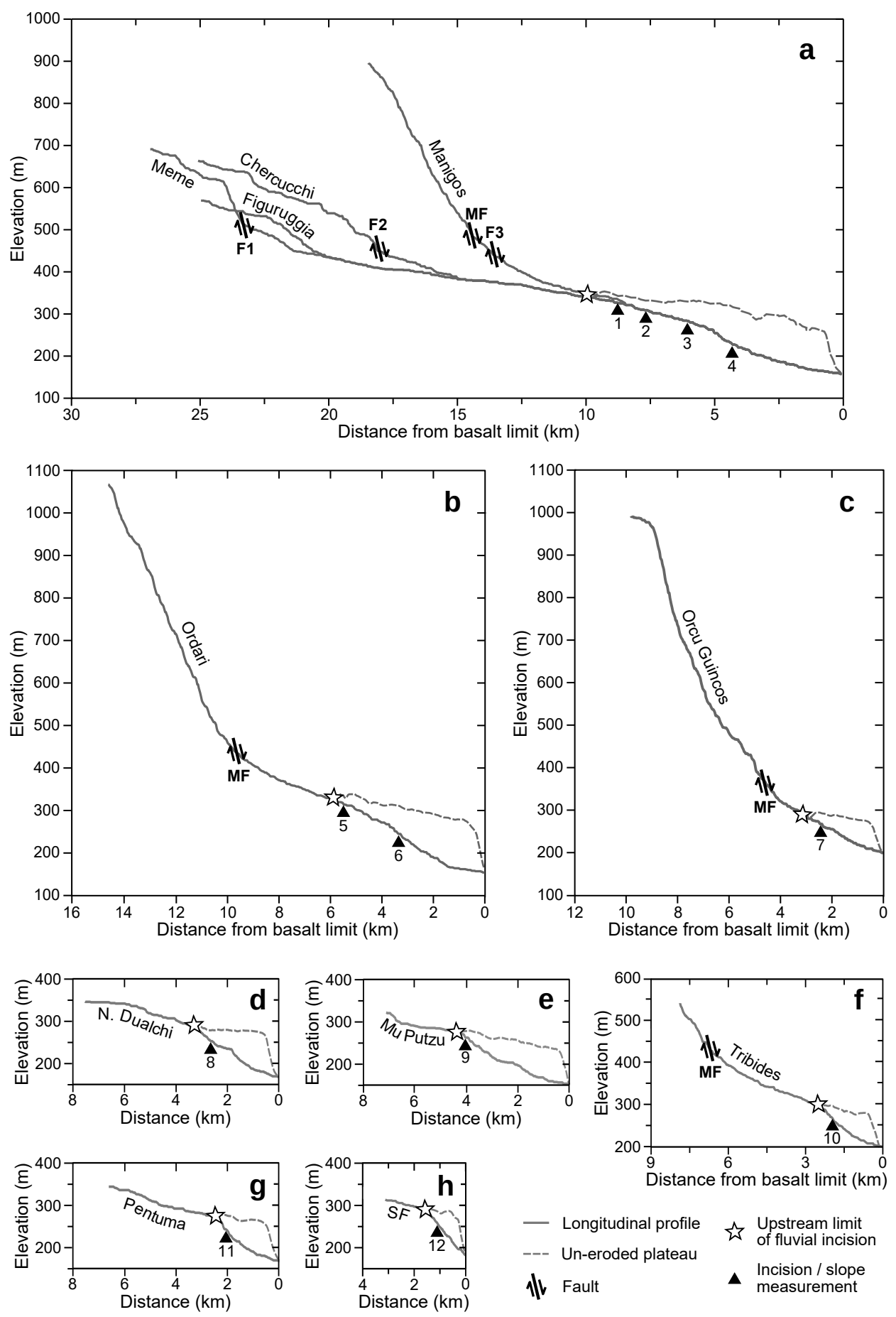

Figure 5: $\mathrm{a}-\mathrm{h}$ ) Longitudinal profiles of rivers used to find erosional parameters, all shown to the same scale. 'N. Dualchi' is the unnamed river north of Dualchi within Figure 3. SF = Su Fruscu river. Basaltic Plains plateau elevation measured from location of adjacent unincised outcrop using SRTM digital elevation model. Elevation measured from sea level. For reference to numbers beneath the slope/incision measurements please see supplementary information Table S1. Faults as labelled on Figure 3. 

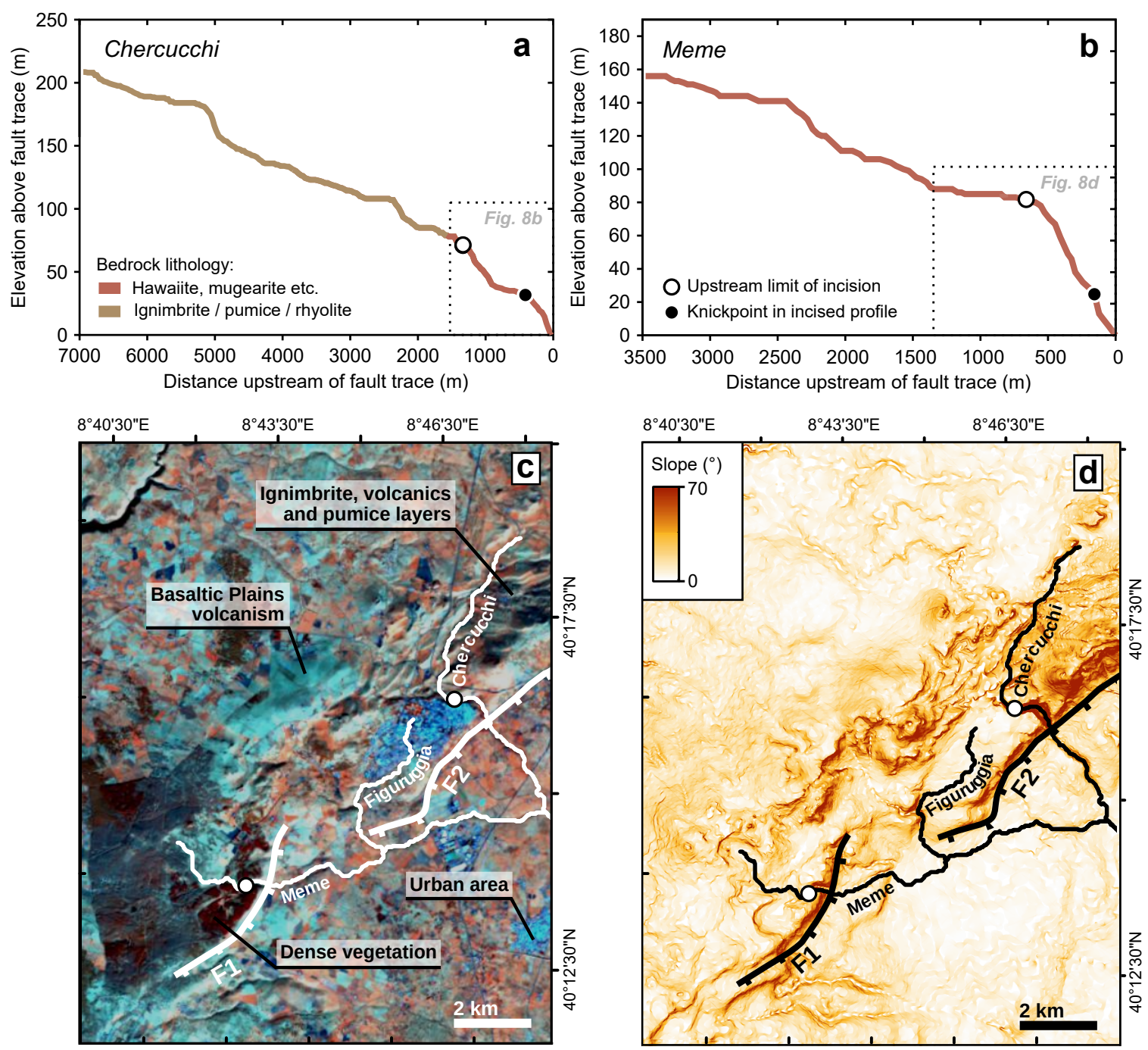

Figure 6: Geomorphic analysis of Meme and Chercucchi longitudinal profiles. a) and b) Chercucchi and Meme longitudinal profiles upstream of faults F2 and F1, respectively. Profiles coloured according to bedrock lithology in Figure 2d. Dashed box denotes profile segment used for numerical inverse modelling. c) Annotated map of faults and rivers on Landsat bands 5,6,7 imagery. d) Faults and rivers on slope map. Black circles denote change from fluvially incised basalt downstream and unincised region upstream.

made on the smallest rivers (Figure 5), though to increase the data spread on the abcissa we made several measurements along the longest rivers, two from the Ordari river, and four from the Meme river. While some measurements from the Meme river do not increase the noticeable spread in data along the $x$-axis in Figure 7 (upstream area ranges between 135 and $140 \mathrm{~km}^{2}$ ), more data at the largest catchment areas should reduce uncertainty in slope and intercept calculation, so we include all four measurements on the Meme river in the following analysis. 
The best nonlinear regression through the data occurs when $n=1.0$ (Figure $7 \mathrm{c}$ ). This very good power law fit implies that, on average, unit stream power $(\partial I / \partial t \propto S)$ provides the most suitable description of fluvial erosion in the study area, suggests constant bedrock erodibility, and validates our assumption of spatially uniform uplift rate since $2.7 \mathrm{Ma}$. The regression line of (Figure $7 \mathrm{c}$ ) has the form $y=a x^{b}$, where $a=0.10$ and $b=0.50$. The bootstrap technique yielded 1 standard error (1 S. E.) uncertainties of 0.02 and 0.04 for erosional parameters $m$ and $k$, respectively. Incision rate, $\mathrm{d} I / \mathrm{d} t$, is therefore proportional to $\mathrm{A}^{0.50 \pm 0.02}$ according to Equations $1 \& 2$. Bedrock erodibility, $k$, equals $0.10 \pm 0.04 \mathrm{~m}^{(1-2 m)} \mathrm{Myr}^{-1}$.

The analysis in Figure 7 uses the average published lava age of $2.7 \mathrm{Ma}$, though if the uncertainty of $\pm 0.2 \mathrm{Myr}$ were applied to this age, the mean $k$ value would still lie in the range $0.09-0.11 \mathrm{~m}^{(1-2 m)} \mathrm{Myr}^{-1}$ and the $m$ and $n$ estimates are unchanged. This analysis suggests that our methodology is relatively insensitive to uncertainties in landscape age and $k=0.10 \pm 0.04 \mathrm{~m}^{(1-2 m)} \mathrm{Myr}^{-1}$ is a robust evaluation of erodibility in the study area.

Aside from the choice of slope measurement and random errors in elevation from the SRTM digital elevation model, which are accounted for using the bootstrap uncertainty procedure, temporal changes in upstream drainage area, $A$, on the low relief Basaltic Plains plateau may add uncertainty to our estimates of parameter values. While it is not straightforward to constrain how the unincised catchment area has changed through geological time, upstream catchment area varies over several orders of magnitude at the measurement locations, so only large losses or gains in catchment area would greatly alter the regression modelling results.

The results obtained using linear least squares regression of the linearised stream power equation (supplementary information Figure S2) are consistent with the nonlinear least squares results pre- 

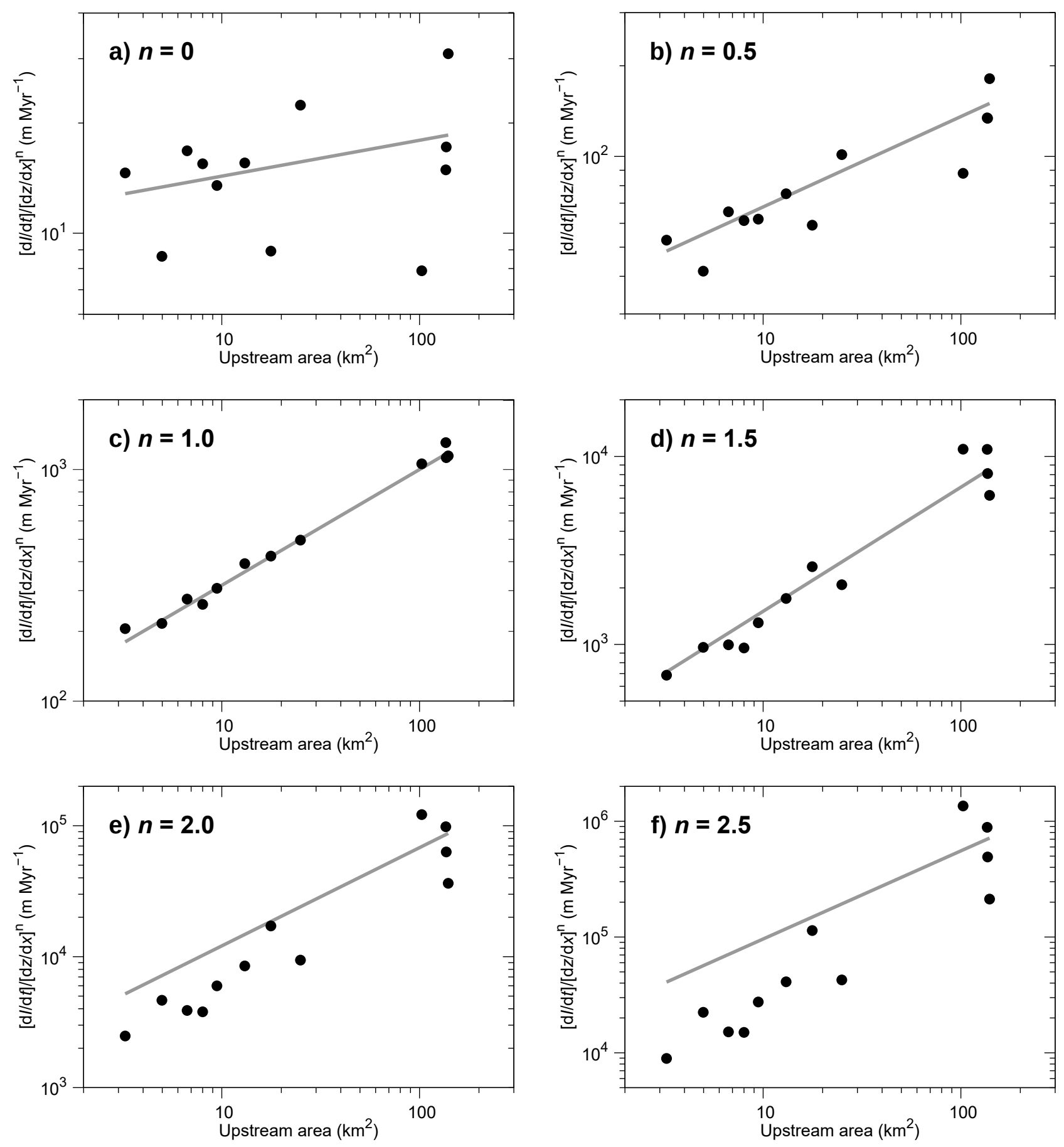

Figure 7: Regressions between upstream area, $A$, and the ratio of incision rate, $\mathrm{d} I / \mathrm{d} t$, and channel slope $\mathrm{d} z / \mathrm{d} x$, as a function of slope exponent, $n$. Dark grey line shows best-fit regression.

sented in Figure 7. For the linearised equation, $n=1$ also produces the smallest residuals between the data and the best fit line, and the best fit erosional parameters are 0.50 for $m$ and 0.10 for $k$, which lie at the centre of the mean \pm one standard error range calculated using nonlinear least squares regression of Equation 1. This similarity in results suggests that our calibration of the stream power equation does not significantly depend upon the choice of regression technique. 


\subsection{Fault throw evolution from numerical inverse modelling}

For the inverse modelling, the Meme and Chercucchi longitudinal profiles upstream of the F1 and F2 fault traces were truncated close to the extent of fault related incision shown on Figure 6. Each shortened river profile segment (Figure $8 \mathrm{~b}$ and d) becomes the observation data for the inverse model, which is the 'target' for the theoretical profiles produced at each inversion run. If $n \neq 1$, then uplift information will be lost as knickpoints migrate upstream (Pritchard et al., 2009; Royden and Perron, 2013). However, our regression analysis supports $n=1$, which implies that knickpoints are preserved in channel longitudinal profiles and an uplift history can be recovered using inverse modelling.

We ran all inverse models with $n=1$, though we systematically varied $m$ and $k$ to encompass the mean \pm two standard errors of these erosional parameters. Therefore, we performed inversion runs with $m$ varying between 0.46 and 0.54 in increments of 0.05 and $k$ varying between 0.02 and $0.18 \mathrm{~m}^{(1-2 m)} \mathrm{Myr}^{-1}$ in increments of 0.01 , which produced a total of 289 inverse model runs for each river.

For the Chercucchi river, 74 of the 289 model runs produced theoretical longitudinal profiles with a trial function, $H<1$ (blue profiles on Figure 8b). These theoretical profiles match the observed profile within the $\approx 3 \mathrm{~m}$ absolute vertical resolution of the SRTM data at most distances upstream of the fault trace (Rodriguez et al., 2005). Model runs that produce a good fit lie in the centre of the range of tested values, and include the mean $m$ and $k$ values of 0.50 and $0.10 \mathrm{~m}^{(1-2 m)} \mathrm{Myr}^{-1}$, respectively (Figure 8a).

Similarly, model runs with relatively large $m$ and/or $k$ values produce a theoretical profiles that suitably match the elevation and knickpoint position of the observed Meme profile (blue profiles of Figure 8d). This result implies that most of the range in $m$ and $k$ predicted by the regression analysis is also 

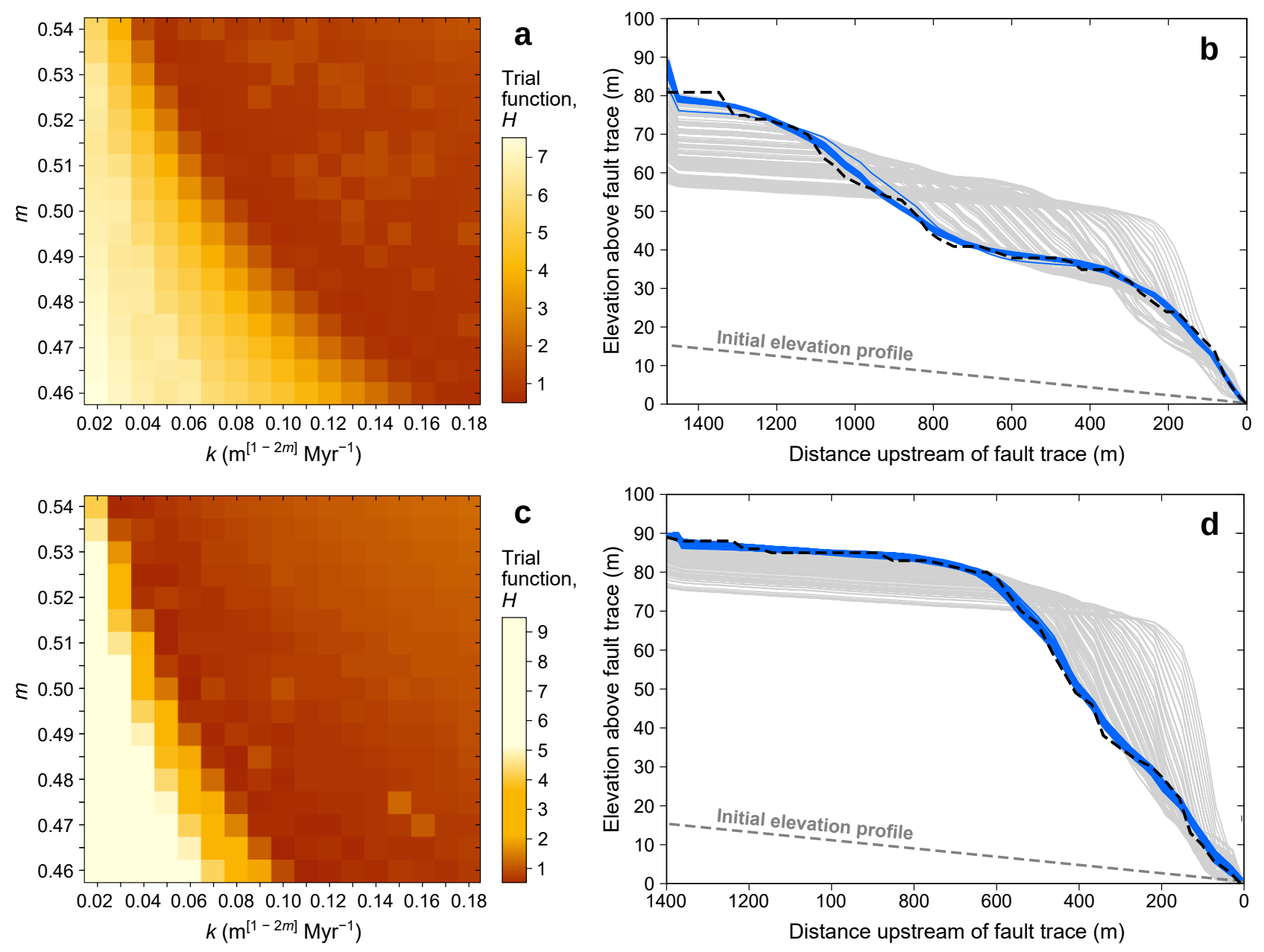

Figure 8: Numerical inverse modelling results: Longitudinal profiles. a) Trial function for Chercucchi river as a function of $m$ and $k$. b) Observed and theoretical longitudinal profiles of the Chercucchi river, upstream of the faults, predicted from numerical inverse modelling. Black dashed profile: observed data from SRTM digital elevation model. Thin blue profiles: Theoretical longitudinal profiles with trial function $<1$. Grey profiles: Theoretical longitudinal profiles with trial function $\geq 1$. c) and d) are the same analyses as panels (a) and (b) for the Meme river.

applicable upstream of fault F1.

The corresponding uplift histories for all theoretical profiles with an acceptable fit to the Chercucchi data show a temporally discontinuous uplift pattern (Figure 9a). For these models, uplift begins between 2.7 and $\approx 1.7 \mathrm{Ma}$. Most models predict no uplift between $\approx 2.0$ and $0.9 \mathrm{Ma}$, and all models share a steady uplift rate of $\approx 0.05 \mathrm{~mm} \mathrm{yr}^{-1}$ from $0.6 \mathrm{Ma}$ to the present day. Even though these models use different combinations of $m$ and $k$, their general similarity implies that this two stage uplift history is a robust result. While we would expect a dissimilar uplift history if $n \neq 1$ or if a 

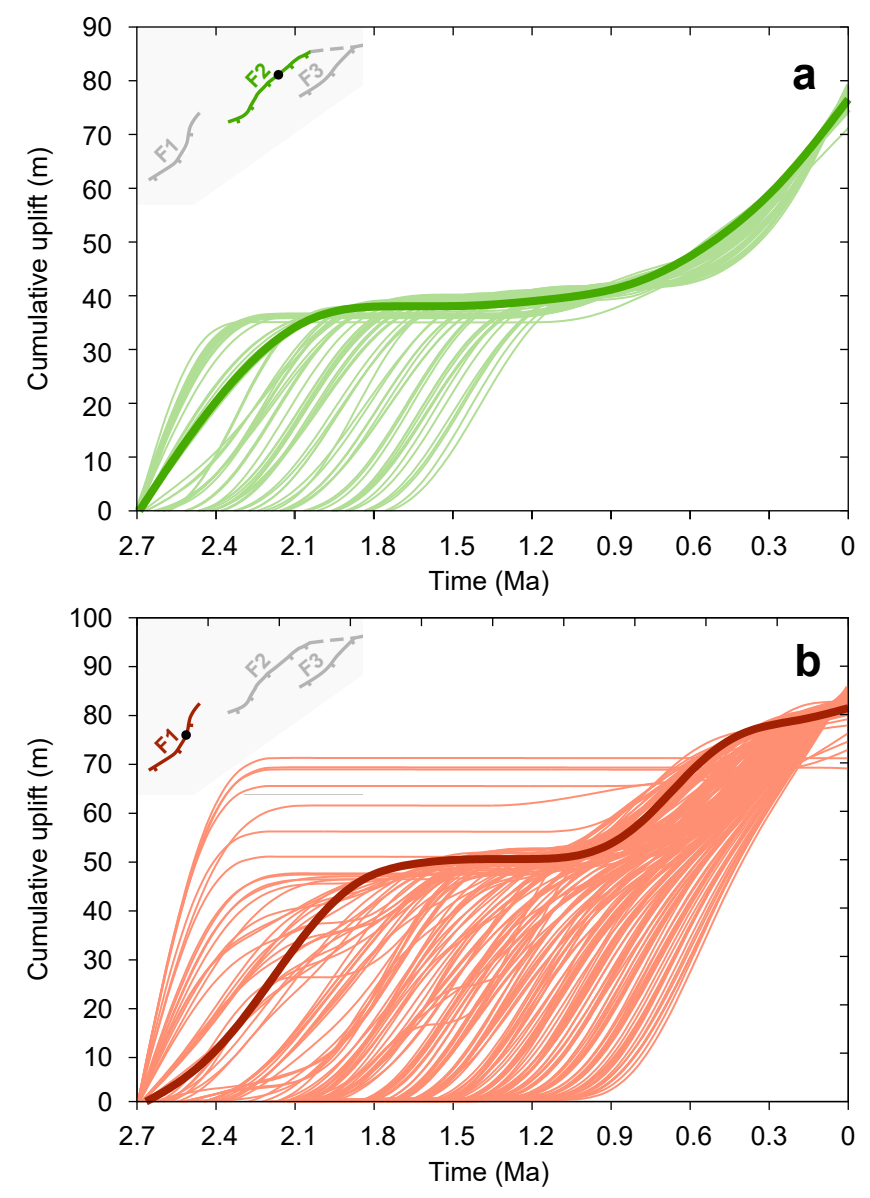

Figure 9: Predicted cumulative uplift that produces well-fitting longitudinal profiles (blue profiles in Figure 8). a) Uplift of fault F2 where Chercucchi river crosses fault. b) Uplift of fault F1 where Meme river crosses fault. Inset map shows relative position of faults, black circles denote where river crosses fault trace. Thick lines are predicted uplift from the best-fitting theoretical longitudinal profiles of the Meme river for fault F1 and Chercucchi river for fault F2.

different combination of $m$ and $k$ were used for the inverse modelling, since the erosional parameter

values used to produce Figures 8 and 9 were independently calculated in the same volcanic landscape

(Section 4.2), and are consistent with the theoretical unit stream power incision model, we do not find a compelling justification to favour a different uplift model for the Chercucchi river.

The uplift history corresponding to the 'best-fitting' theoretical Meme profile predicts similar uplift rates to the Chercucchi river (Figure 9a, thick line). The Meme's best-fit uplift rate is relatively high $\left(\approx 0.08 \mathrm{~mm} \mathrm{yr}^{-1}\right)$ between 2.4 and $2.0 \mathrm{Ma}$. Mirroring the uplift predicted by the best fitting Chercucchi profile, this uplift model for the Meme does not reveal any footwall uplift between 1.8 and 1.0 Ma, 
though uplift subsequently resumes at rates $\leq 0.05 \mathrm{~mm} \mathrm{yr}^{-1}$ (Figure 9b). Since the best-fit uplift history predicts $\approx 10 \mathrm{~m}$ of uplift in the last $0.5 \mathrm{Ma}$, we may conclude that F2 is also an active fault, albeit with a very slow late Pleistocene throw rate $\left(<0.02 \mathrm{~mm} \mathrm{yr}^{-1}\right)$. However, we acknowledge that this uplift history is poorly constrained because a range of uplift models fit the observed longitudinal profile (Figures $8 \mathrm{~d}$ and 9b). For example, some theoretical river profiles with $H<1$ correspond to uplift models where faulting begins at $\approx 1 \mathrm{Ma}$ and throw rates are approximately constant at $\approx 0.09$ $\mathrm{mm} \mathrm{yr}^{-1}$ until the present day, while other, equally well fitting, uplift models predict that all activity on fault F1 occurred between 2.7 and $2.4 \mathrm{Ma}$ (Figure $9 \mathrm{~b}$ ).

The possibility of either constant or temporally variable throw rates for fault F1 indicates that the apparent uplift rate history for the Meme river is very sensitive to the $m$ and $k$ values chosen for analysis. The combination of regression techniques to calibrate the stream power equation and fluvial inverse modelling has revealed this sensitivity, and potentially highlights the advantages of fluvial inverse modelling compared to more qualitative longitudinal profile analysis.

The Meme and Chercucchi rivers cross F1 and F2 near the centre of the faults, where observed throw is close to the maximum (Figure 4a,b). Throw rates typically vary along strike and decrease towards fault tips (e.g. Cowie and Roberts, 2001; Papanikolaou and Roberts, 2007; Nicol et al., 2010). Therefore, the throw rates estimated by fluvial inversion from 0.9 Ma to present may be the largest experienced by these faults over this time period. 


\section{Discussion}

\subsection{Evaluation of stream power calibration method}

The regression methodology outlined in this paper details a straightforward and reliable way to evaluate erodibility, and test erosion laws, using freely available remote sensing data. The Basaltic Plains are suitable for such analysis because bedrock geology is invariant and all rivers close to the outcrop boundary have probably experienced the same relative uplift history. The incised portions of all rivers in the study area also lie within Plio-Pleistocene basaltic flows, so it is reasonable to assume that landscape age, $\mathrm{d} t$, does not vary between rivers. Although these conditions are specific to the Basaltic Plains, we envision that this technique could be applied elsewhere, assuming certain geological and geomorphological conditions are met. The study area should ideally contain: a) multiple rivers incising into a landscape of the same age (the age must be known to evaluate $k$ ), b) relatively low relief pre-incision topography and insignificant hillslope erosion (so incision can be reliably measured), and c) stable drainage divides (so $A$ is not a function of time). Therefore, this method should work well in other volcanic transient landscapes, as volcanism creates both a low relief surface (lava flows), and a new local drainage divide (volcanic eruption centres).

\subsection{Comparison of erosional parameters to existing work}

Our results indicate a linear proportionality between erosion rate and channel slope, which has been assumed by many studies that used longitudinal profiles to quantify geological history or surface processes, is appropriate in this kind of landscape (Section 1). While we acknowledge that some longitudinal profile analyses have indicated $\mathrm{n}<1$ (e.g. Royden and Perron, 2013; Gallen and Wegmann, 2017), or $n>1$ (e.g. Whittaker and Boulton, 2012), our results are consistent with commonly used fluvial erosional models. In addition, most studies that have used numerical inversion of large num- 
bers longitudinal profiles to find value of slope exponent, $n$, produce low misfit inversions if $n \approx 1$ (e.g. Roberts and White, 2010; Fox et al., 2014; Glotzbach, 2015; Rudge et al., 2015; Richards et al., 2016; Rodríguez Tribaldos et al., 2017), equivalent to the results produced using the methodological approach outlined in this study. Therefore, our results imply that catchment scale fluvial erosion can be consistent with continental scale fluvial erosion.

Our $m$ value of $0.50 \pm 0.02$ lies within the range predicted by other authors (e.g. Paul et al., 2014; Glotzbach, 2015; Murphy et al., 2016; Stucky de Quay et al., 2019), is consistent with observed knickpoint retreat as a function of upstream area (Bishop et al., 2005; Kent et al., 2017), and is equivalent to the $E \propto A^{0.5}$ relationship that may be expected if discharge is linearly proportional to catchment area and channel width is proportional to the square root of discharge (e.g. Whittaker and Boulton, 2012). However, the bedrock erodibility, $k$, value of $0.10 \pm 0.04 \mathrm{~m}^{(1-2 m)} \mathrm{Myr}^{-1}$ is relatively small, even if compared to equivalent measures derived from analysis of other basaltic landscapes (e.g. Staisch et al., 2018; Stucky de Quay et al., 2019). A small $k$ value implies a long landscape response time, which is the ability to retain tectonic or climate signals in topography. Loget and Van Den Driessche (2009) suggest that high porosity bedrock could retard knickpoint retreat rates in volcanic landscapes, but this is unlikely to explain the value for the basaltic lithologies in the study area. Instead, the low vesicular basalts in central Sardinia have low porosity, and were historically mined for their high durability (e.g. Blake, 1998; Antonelli and Lazzarini, 2010; Careddu and Grillo, 2019), which suggests that the rocks are generally not heavily fractured or highly weathered. Therefore, low erodibility may be related to an intrinsic property of the Basaltic Plains rocks.

However, Whittaker and Boulton (2012) investigated the relationship between uplift rate and landscape response time of rivers incising mainly hard limestone bedrock upstream of faults in the Italian Apennines and Turkey, for which they derived the relationship $\Psi_{A}=R^{0.67}$, where $\Psi_{A}$ is equivalent 


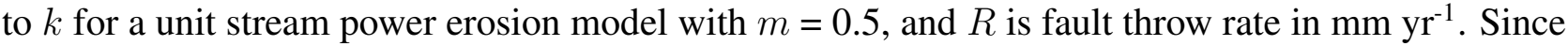
fault throw is the vertical component of displacement, throw will be substituted for uplift rate in this study. For the Basaltic Plains, the average 'uplift rate' is $\approx 0.04 \mathrm{~mm} \mathrm{yr}^{-1}$ (derived from $\sim 100 \mathrm{~m}$ of relief inversion since $2.7 \mathrm{Ma}$ ), which corresponds to $\Psi_{A}=0.12 \mathrm{~m}^{(1-2 m)} \mathrm{Myr}^{-1}$ or $1.2 \times 10^{-7} \mathrm{yr}^{-1}$ in the units preferred by Whittaker and Boulton. This $\Psi_{A}$ value lies within the one standard error range of erodibility, $k$, derived from regression of incision, slope and area measurements in Figure 7c. Therefore, our analysis in this paper is also consistent with data that suggest low uplift rates generate slow landscape response times. Whether intrinsic material properties, uplift rate, or other factors such as fracture density are the cause of the apparently low $k$ value is beyond the scope of this study, but could be the focus of further work in the Basaltic Plains.

\subsection{Implications for Pliocene-Recent tectonic activity of Sardinia}

At a local scale, the presence of normal faults that offset the Plio-Pleistocene Basaltic Plains surface suggests that local extension has occurred in central Sardinia since approximately 2.7 Ma. The strike of normal faults F1-3 (Figure 3) is similar to the predicted orientation of the buried Tirso River fault proposed by Andriani et al. (2001), so also appears to support the presence of a pull apart basin between the main Tavolara and Nuoro faults that was proposed by these authors.

The pattern of footwall uplift rates that we predict from inverse modelling is fairly similar for faults F1 and F2 (Figure 9), and this similarity suggests that river profile morphology records regional tectonic stresses in the Basaltic Plains, since long term fault activity is generally similar for adjacent continually active faults in a fault array. Faults F1-F3 have developed on young volcanic rocks, which may not be subject to the structural inheritance of older structures (see Section 2). Therefore, in the absence of any large scale fractures, or other heterogeneities, fault orientations should reflect the local stress field. The smallest compressive stress vector for Faults F1-3 would be locally orien- 
tated NW-SE. This orientation is similar to surface faults in the southern Tyrrhenian Sea and in the Italian region of Calabria (e.g. Monaco and Tortorici, 2000; Catalano et al., 2008). Therefore, at a larger scale, a possible interpretation is that faults $1-3$ formed in response to the late Miocene-Present extension caused by the migrating arcs of the central Mediterranean region (e.g. Sartori et al., 2001; Catalano et al., 2003; Doglioni et al., 2004; Rosenbaum and Lister, 2004; Galli et al., 2007). Alternatively, the faults in the Basaltic Plains may be conjugate structures of the Plio-Pleistocene Sicily Channel rift, a graben system south of Sardinia that has formed orthogonal to the main compressive structures of the region, and which may connect to the onshore Campidano graben just south of the study area (Corti et al., 2006).

While the analysis of this paper does not consider the Pliocene-Recent tectonic activity for the whole island, our fluvial inverse modelling results imply that landscape change caused by faulting can be resolved in areas of historically low tectonic activity such as Sardinia. For fault F2, we estimate that several metres of this landscape change occurred during the most recent glacial-interglacial cycles (MIS 5 to present), consistent with the interpretations of Mariani et al. (2009), Polyak et al. (2018) and Cocco et al. (2019) who suggested tectonic activity in coastal regions over similar time periods. We propose that quantitative analysis of long-term uplift using fluvial erosion modelling could help identify other late Pleistocene-Recent tectonically active areas of Sardinia, and any inferred tectonic activity should be considered in Pleistocene sea level reconstructions.

\section{Conclusions}

We have used a transient fluvial landscape in central Sardinia to calibrate a stream power erosion equation, and utilised the parameters from this calibration in a numerical inverse model that calculated fault uplift from longitudinal profile morphology. Results from the erosional model calibration 
suggest incision rate is linearly proportional to channel slope (slope exponent, $n=1$ ), and proportional to the square root of upstream drainage area (area exponent $m=0.50 \pm 0.02$ ), consistent with theoretical models of fluvial erosion. The calculated bedrock erodibility, $k$ in the stream power model, was $0.10 \pm 0.04 \mathrm{~m}^{(1-2 m)} \mathrm{Myr}^{-1}$. Three normal faults have a topographic expression in the Plio-Pleistocene basaltic outcrop of the study area, and slip on two of these normal faults appears to have produced knickpoints on upstream sections of the Meme and Chercucchi rivers. Numerical inverse modelling of the longitudinal profile segments that contain these knickpoints predicts a temporally discontinuous uplift history for both faults. The normal fault near Macomer (F2) may have been recently active according to the output of the inverse model with an average throw rate of $0.05 \mathrm{~m} \mathrm{Myr}^{-1}$ for the last $600 \mathrm{ka}$. Estimated throw rates for the fault in the south of the study area (F1) are less well constrained by inverse modelling, but the best fit uplift history implies throw rates

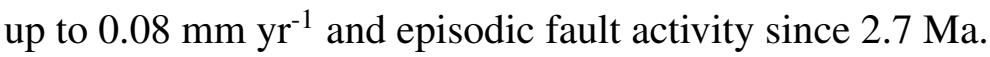

\section{Acknowledgements}

The authors would like to thank Alain Demoulin, Ed Keller and Wolfgang Schwanghart for helpful and constructive reviews that improved the paper. This research was funded by a Natural Environment Research Council studentship to JQS.

\section{References}

V. Akgul, K. Becek, and J. Grossek. Assessment of the vertical accuracy of SRTM-1" data over the territory of Poland using the runway method. Geomatics, Landmanagement and Landscape, 2017. doi: 10.15576/GLL/2017.3.7.

W. Alvarez. Rotation of the Corsica-Sardinia microplate. Nature, 235(58):103-105, 1972. doi: 10.1038/physci235103a0. 
S. Andreucci, L. B. Clemmensen, and V. Pascucci. Transgressive dune formation along a cliffed coast at $75 \mathrm{ka}$ in Sardinia, Western Mediterranean: a record of sea-level fall and increased windiness. Terra Nova, 22(6):424-433, 2010. doi: 10.1111/j.1365-3121.2010.00971.x.

T. Andriani, R. Balia, M. Loddo, G. Pecorini, and A. Tramacere. Structural features of the Middle Tirso Valley (Central Sardinia-Italy) from geoelectrical and gravity data. Annals of Geophysics, 44 (4):739-753, 2001.

M. Angelone, C. Gasparini, M. Guerra, S. Lombardi, L. Pizzino, F. Quattrocchi, E. Sacchi, and G. Zuppi. Fluid geochemistry of the Sardinian Rift-Campidano Graben (Sardinia, Italy): fault segmentation, seismic quiescence of geochemically "active" faults, and new constraints for selection of $\mathrm{CO}_{2}$ storage sites. Applied Geochemistry, 20(2):317-340, 2005. doi: 10.1016/j.apgeochem.2004.08.008.

F. Antonelli and L. Lazzarini. Mediterranean trade of the most widespread Roman volcanic millstones from Italy and petrochemical markers of their raw materials. Journal of Archaeological Science, 37(9):2081-2092, 2010. doi: 10.1016/j.jas.2010.02.008.

M. Attal, P. Cowie, A. Whittaker, D. Hobley, G. Tucker, and G. Roberts. Testing fluvial erosion models using the transient response of bedrock rivers to tectonic forcing in the Apennines, Italy. Journal of Geophysical Research, 116:F02005, 2011. doi: 10.1029/2010JF001875.

L. Beccaluva, M. Deriu, G. Macciotta, C. Savelli, and G. Venturelli. Geochronology and magmatic character of the Pliocene-Pleistocene volcanism in Sardinia (Italy). Bulletin volcanologique, 40 (3):153-168, 1977. doi: 10.1007/BF02596997.

L. Beccaluva, L. Civetta, G. Macciotta, and C. A. Ricci. Geochronology in Sardinia: results and problems. Rendiconti della Società Italiana di Mineralogica e Petrologica, 40:57-72, 1985.

L. Beccaluva, G. Macciotta, F. Siena, and O. Zeda. Harzburgite-lherzolite xenoliths and clinopyrox- 
ene megacrysts of alkaline basic lavas from Sardinia (Italy). Chemical geology, 77(3-4):331-345, 1989. doi: 10.1016/0009-2541(89)90082-X.

K. Becek, V. Akgül, S. Inyurt, Ç. Mekik, and P. Pochwatka. How well can spaceborne digital elevation models represent a man-made structure: A runway case study. Geosciences, 9(9):387, 2019. doi: 10.3390/geosciences9090387.

A. Beckers, B. Bovy, E. Hallot, and A. Demoulin. Controls on knickpoint migration in a drainage network of the moderately uplifted Ardennes Plateau, Western Europe. Earth Surface Processes and Landforms, 40(3):357-374, 2015. doi: 10.1002/esp.3638.

P. Bishop, T. B. Hoey, J. D. Jansen, and I. L. Artza. Knickpoint recession rate and catchment area: the case of uplifted rivers in Eastern Scotland. Earth Surface Processes and Landforms, 30(6): 767-778, 2005. doi: 10.1002/esp.1191.

E. Blake. Sardinia's nuraghi: four millennia of becoming. World Archaeology, 30(1):59-71, 1998. doi: 10.1080/00438243.1998.9980397.

S. J. Boulton and M. Stokes. Which DEM is best for analyzing fluvial landscape development in mountainous terrains? Geomorphology, 310:168-187, 2018. doi: 10.1016/j.geomorph.2018.03.002.

S. J. Boulton and A. C. Whittaker. Quantifying the slip rates, spatial distribution and evolution of active normal faults from geomorphic analysis: Field examples from an obliqueextensional graben, southern Turkey. Geomorphology, 104(3-4):299-316, 2009. doi: 10.1016/j.geomorph.2008.09.007.

G. Brocard and P. van der Beek. Influence of incision rate, rock strength, and bedload supply on bedrock river gradients and valley-flat widths: Field-based evidence and calibrations from western Alpine rivers (southeast France). In S. Willett, N. Hovius, M. Brandon, and D. Fisher, editors, 
Tectonics, Climate, and Landscape Evolution: Geological Society of America Special Paper 398, pages 101-126, 2006. doi: 10.1130/2006.2398(07).

N. Careddu and S. M. Grillo. Sardinian basalt-an ancient georesource still en vogue. Geoheritage, 11(1):35-45, 2019. doi: doi.org/10.1007/s12371-018-0285-0.

L. Carmignani, G. Oggiano, A. Funedda, P. Conti, and S. Pasci. The geological map of Sardinia (Italy) at 1:250,000 scale. Journal of Maps, 12:826-835, 2015. doi: 10.1080/17445647.2015.1084544.

E. Carminati, M. Lustrino, and C. Doglioni. Geodynamic evolution of the central and western Mediterranean: Tectonics vs. igneous petrology constraints. Tectonophysics, 579:173-192, 2012. doi: 10.1016/j.tecto.2012.01.026.

G. Casula, A. Cherchi, L. Montadert, M. Murru, and E. Sarria. The Cenozoic graben system of Sardinia (Italy): geodynamic evolution from new seismic and field data. Marine and Petroleum Geology, 18(7):863-888, 2001. doi: 0.1016/S0264-8172(01)00023-X.

S. Catalano, G. De Guidi, C. Monaco, G. Tortorici, and L. Tortorici. Long-term behaviour of the late Quaternary normal faults in the Straits of Messina area (Calabrian arc): structural and morphological constraints. Quaternary International, 101-102:81-91, 2003. doi: 10.1016/S10406182(02)00091-5.

S. Catalano, G. De Guidi, C. Monaco, G. Tortorici, and L. Tortorici. Active faulting and seismicity along the Siculo-Calabrian Rift Zone (Southern Italy). Tectonophysics, 453(1-4):177-192, 2008. doi: 10.1016/j.tecto.2007.05.008.

F. Cocco, S. Andreucci, D. Sechi, G. Cossu, and A. Funedda. Upper Pleistocene tectonics in western Sardinia (Italy): insights from the Sinis peninsula structural high. Terra Nova, 31:485-493, 2019. doi: $10.1111 /$ ter.12418. 
D. Commins, S. Gupta, and J. Cartwright. Deformed streams reveal growth and linkage of a normal fault array in the Canyonlands graben, Utah. Geology, 33(8):645-648, 2005. doi: 10.1130/G21433AR.1.

G. Corti, M. Cuffaro, C. Doglioni, F. Innocenti, and P. Manetti. Coexisting geodynamic processes in the Sicily Channel. Special Papers-Geological Society of America, 409:83-96, 2006. doi: $10.1130 / 2006.2409(05)$.

P. A. Cowie and G. P. Roberts. Constraining slip rates and spacings for active normal faults. Journal of Structural Geology, 23(12):1901-1915, 2001. doi: 10.1016/S0191-8141(01)00036-0.

M. D'Arcy and A. C. Whittaker. Geomorphic constraints on landscape sensitivity to climate in tectonically active areas. Geomorphology, 204:366-381, 2014. doi: 10.1016/j.geomorph.2013.08.019.

R. Deiana, I. Dieni, F. Massari, M. T. Perri, M. Rossi, and A. Brovelli. A multi-disciplinary study of deformation of the basaltic cover over fine-grained valley fills: a case study from Eastern Sardinia, Italy. International Journal of Earth Sciences, 105(4):1245-1255, 2015. doi: 10.1007/c00531015-1230-y.

C. Doglioni, F. Innocenti, C. Morellato, D. Procaccianti, and D. Scrocca. On the tyrrhenian sea opening. Memorie Descrittive della Carta Geologica d'Italia, 64:147-164, 2004.

R. Duncan, S. Ginesu, F. Secchi, and S. Sias. The recent evolution of the Sinis region (western coast of Sardinia, Italy) on the basis of new radiometric data of the Pliocenic volcanism. Geografia Fisica e Dinamica Quaternaria, 34:2-10, 2011.

C. J. Ebinger, J. A. Jackson, A. N. Foster, and N. J. Hayward. Extensional basin geometry and the elastic lithosphere. Philosophical Transactions of the Royal Society of London. Series A: Mathematical, Physical and Engineering Sciences, 357(1753):741-765, 1999. doi: 10.1098/rsta.1999.0351. 
J. Eronen, K. Puolamäki, L. Liu, K. Lintulaakso, J. Damuth, C. Janis, and M. Fortelius. Precipitation and large herbivorous mammals II: application to fossil data. Evolutionary Ecology Research, 12 (2):235-248, 2010.

C. Faccenna, F. Speranza, F. D. Caracciolo, M. Mattei, and G. Oggiano. Extensional tectonics on Sardinia (Italy): insights into the arc-back-arc transitional regime. Tectonophysics, 356(4):213232, 2002. doi: 10.1016/S0040-1951(02)00287-1.

K. L. Ferrier, K. L. Huppert, and J. T. Perron. Climatic control of bedrock river incision. Nature, 496 (7444):206-209, 2013. doi: 10.1038/nature11982.

A. M. Forte, B. J. Yanites, and K. X. Whipple. Complexities of landscape evolution during incision through layered stratigraphy with contrasts in rock strength. Earth Surface Processes and Landforms, 41(12):1736-1757, 2016. doi: 10.1002/esp.3947.

M. Fox, L. Goren, D. A. May, and S. D. Willett. Inversion of fluvial channels for paleorock uplift rates in Taiwan. Journal of Geophysical Research: Earth Surface, 119(9):1853-1875, 2014. doi: 10.1002/2014JF003196.

A. Funedda, G. Oggiano, and S. Pasci. The Logudoro Basin; a key area for the Tertiary tectonosedimentary evolution of north Sardinia. Bollettino della Società Geologica Italiana, 119(1):31$38,2000$.

S. F. Gallen and K. W. Wegmann. River profile response to normal fault growth and linkage: An example from the Hellenic forearc of south-central Crete, Greece. Earth Surface Dynamics, 5(1): 161-186, 2017. doi: 10.5194/esurf-5-161-2017.

P. Galli, V. Scionti, and V. Spina. New paleoseismic data from the Lakes and Serre faults: seismotectonic implications for Calabria (Southern Italy). Bollettino della Società Geologica Italiana, 126 (2):347-364, 2007. 
G. K. Gilbert. The Colorado Plateau Province as a field for geological study. Tuttle, Morehouse \& Taylor, 1876.

C. Glotzbach. Deriving rock uplift histories from data-driven inversion of river profiles. Geology, 43 (6):467-470, 2015. doi: 10.1130/G36702.1.

L. Goren, M. Fox, and S. D. Willett. Tectonics from fluvial topography using formal linear inversion: Theory and applications to the Inyo Mountains, California. Journal of Geophysical Research: Earth Surface, 119(8):1651-1681, 2014. doi: 10.1002/2014JF003079.

A. Gupta and C. H. Scholz. Utility of elastic models in predicting fault displacement fields. Journal of Geophysical Research: Solid Earth, 103(B1):823-834, 1998. doi: 10.1029/97JB03009.

G. Hancock and K. Evans. Channel head location and characteristics using digital elevation models. Earth Surface Processes and Landforms, 31(7):809-824, 2006. doi: 10.1002/esp.1285.

R. A. Hartley, G. G. Roberts, N. White, and C. Richardson. Transient convective uplift of an ancient buried landscape. Nature Geoscience, 4(8):562-565, 2011. doi: 10.1038/ngeo1191.

H. Helbing, W. Frisch, P. D. Bons, and J. Kuhlemann. Tension gash-like back-arc basin opening and its control on subduction rollback inferred from Tertiary faulting in Sardinia. Tectonics, 25(4): TC4008, 2006. doi: 10.1029/2005TC001904.

A. D. Howard. A detachment-limited model of drainage basin evolution. Water resources research, 30(7):2261-2285, 1994. doi: 10.1029/94WR00757.

P. Hughes and J. Woodward. Quaternary glaciation in the Mediterranean mountains: a new synthesis. Geological Society, London, Special Publications, 433(1):1-23, $2017 . \quad$ doi: doi.org/10.1144/SP433.14.

M. L. Jeffery, T. A. Ehlers, B. J. Yanites, and C. J. Poulsen. Quantifying the role of paleoclimate and 
Andean Plateau uplift on river incision. Journal of Geophysical Research: Earth Surface, 118(2): 852-871, 2013. doi: 10.1002/jgrf.20055.

L. Karlstrom, P. W. Richardson, D. O'Hara, and S. K. Ebmeier. Magmatic landscape construction. Journal of Geophysical Research: Earth Surface, 123(8):1710-1730, 2018. doi: 10.1029/2017JF004369.

E. Kent, S. J. Boulton, A. C. Whittaker, I. S. Stewart, and M. Cihat Alçiçek. Normal fault growth and linkage in the Gediz (Alaşehir) Graben, Western Turkey, revealed by transient river long-profiles and slope-break knickpoints. Earth Surface Processes and Landforms, 42(5):836-852, 2017. doi: 10.1002/esp.4049.

E. Kirby and K. Whipple. Quantifying differential rock-uplift rates via stream profile analysis. Geology, 29(5):415-418, 2001. doi: 10.1130/0091-7613(2001)029<0415:qdrurv>2.0.co;2.

E. Kirby and K. X. Whipple. Expression of active tectonics in erosional landscapes. Journal of Structural Geology, 44:54-75, 2012. doi: 10.1016/j.jsg.2012.07.009.

N. Loget and J. Van Den Driessche. Wave train model for knickpoint migration. Geomorphology, 106(3-4):376-382, 2009. doi: 10.1016/j.geomorph.2008.10.017.

L. Lonergan and N. White. Origin of the Betic-Rif mountain belt. Tectonics, 16(3):504-522, 1997. doi: $10.1029 / 96 \mathrm{TC} 03937$.

M. Lustrino, L. Melluso, and V. Morra. The role of lower continental crust and lithospheric mantle in the genesis of Plio-Pleistocene volcanic rocks from Sardinia (Italy). Earth and Planetary Science Letters, 180(3):259-270, 2000. doi: 10.1016/S0012-821X(00)00185-0.

M. Lustrino, V. Morra, L. Melluso, P. Brotzu, F. d'Amelio, L. Fedele, L. Franciosi, R. Lonis, and A. M. P. Liebercknecht. The Cenozoic igneous activity of Sardinia. Periodico di Mineralogia, 73 (Special issue 1):105-134, 2004. 
M. Lustrino, L. Melluso, and V. Morra. The geochemical peculiarity of "Plio-Quaternary" volcanic rocks of Sardinia in the circum-Mediterranean area. Geological Society of America Special Papers, 418:277-301, 2007. doi: 10.1130/2007.2418(14).

A. Malinverno and W. B. Ryan. Extension in the Tyrrhenian Sea and shortening in the Apennines as result of arc migration driven by sinking of the lithosphere. Tectonics, 5(2):227-245, 1986. doi: 10.1029/TC005i002p00227.

P. Mariani, C. Braitenberg, and F. Antonioli. Sardinia coastal uplift and volcanism. Pure and applied geophysics, 166(8-9):1369-1402, 2009. doi: 10.1007/s00024-009-0504-3.

A. Mauffret, I. Contrucci, and C. Brunet. Structural evolution of the Northern Tyrrhenian Sea from new seismic data. Marine and Petroleum Geology, 16(5):381-407, 1999. doi: 10.1016/S02648172(99)00004-5.

M. Melis, F. Mundula, F. Dessì, R. Cioni, and A. Funedda. Tracing the boundaries of Cenozoic volcanic edifices from Sardinia (Italy): a geomorphometric contribution. Earth Surface Dynamics, 2(2):481-492, 2014. doi: 10.5194/esurf-2-481-2014.

J. R. Miller. The Influence of Bedrock Geology on Knickpoint Development and Channel-Bed Degradation along Downcutting Streams in South-Central Indiana. The Journal of Geology, 99(4):591605, 1991. doi: 10.1086/629519.

S. R. Miller, S. L. Baldwin, and P. G. Fitzgerald. Transient fluvial incision and active surface uplift in the Woodlark Rift of eastern Papua New Guinea. Lithosphere, 4(2):131-149, 2012. doi: 10.1130/L135.1.

C. Monaco and L. Tortorici. Active faulting in the Calabrian arc and eastern Sicily. Journal of Geodynamics, 29(3-5):407-424, 2000. doi: 10.1016/S0264-3707(99)00052-6. 
B. P. Murphy, J. P. Johnson, N. M. Gasparini, and L. S. Sklar. Chemical weathering as a mechanism for the climatic control of bedrock river incision. Nature, 532(7598):223-227, 2016. doi: 10.1038/nature17449.

A. Nicol, J. Walsh, P. Villamor, H. Seebeck, and K. Berryman. Normal fault interactions, paleoearthquakes and growth in an active rift. Journal of Structural Geology, 32(8):1101-1113, 2010. doi: 10.1016/j.jsg.2010.06.018.

J. D. Niemann, N. M. Gasparini, G. E. Tucker, and R. L. Bras. A quantitative evaluation of Playfair's law and its use in testing long-term stream erosion models. Earth Surface Processes and Landforms, 26(12):1317-1332, 2001. doi: 10.1002/esp.272.

G. Oggiano, A. Funedda, L. Carmignani, and S. Pasci. The Sardinia-Corsica microplate and its role in the Northern Apennine Geodynamics: new insights from the Tertiary intraplate strike-slip tectonics of Sardinia. Bollettino della Società Geologica Italiana, 128(2):527-539, 2009. doi: 10.3301/IJG.2009.128.2.527.

C. Ollier. The Great Escarpment of eastern Australia: tectonic and geomorphic significance. Journal of the Geological Society of Australia, 29(1-2):13-23, 1982. doi: 10.1080/00167618208729190.

S. Orlandini, P. Tarolli, G. Moretti, and G. Dalla Fontana. On the prediction of channel heads in a complex alpine terrain using gridded elevation data. Water Resources Research, 47(2):W02538, 2011. doi: 10.1029/2010WR009648.

I. D. Papanikolaou and G. P. Roberts. Geometry, kinematics and deformation rates along the active normal fault system in the southern Apennines: Implications for fault growth. Journal of Structural Geology, 29(1):166-188, 2007. doi: 10.1016/j.jsg.2006.07.009.

S. Pasci. Tertiary transcurrent tectonics of north-central Sardinia. Bulletin de la Société Géologique de France, 168(3):301-312, 1997. 
J. D. Paul, G. G. Roberts, and N. White. The African landscape through space and time. Tectonics, 33(6):898-935, 2014. doi: 10.1002/2013TC003479.

F. Pavano, F. J. Pazzaglia, and S. Catalano. Knickpoints as geomorphic markers of active tectonics: A case study from northeastern Sicily (southern Italy). Lithosphere, 8(6):633-648, 12 2016. doi: 10.1130/L577.1.

J. V. Pérez-Peña, M. Al-Awabdeh, J. M. Azañón, J. P. Galve, G. Booth-Rea, and D. Notti. SwathProfiler and NProfiler: Two new ArcGIS Add-ins for the automatic extraction of swath and normalized river profiles. Computers \& Geosciences, 104:135-150, 2017. doi: 10.1016/j.cageo.2016.08.008.

V. J. Polyak, B. P. Onac, J. J. Fornós, C. Hay, Y. Asmerom, J. A. Dorale, J. Ginés, P. Tuccimei, and A. Ginés. A highly resolved record of relative sea level in the western Mediterranean Sea during the last interglacial period. Nature Geoscience, 11(11):860-864, 2018. doi: 10.1038/s41561-0180222-5.

D. Pritchard, G. Roberts, N. White, and C. Richardson. Uplift histories from river profiles. Geophysical Research Letters, 36(24):L24301, 2009. doi: 10.1029/2009GL040928.

Regione Autonoma della Sardegna, 2020. Hydrology map DGB10K. Regione Autonoma della Sardegna. URL www.sardegnageoportale.it.

F. Richards, M. Hoggard, and N. White. Cenozoic epeirogeny of the Indian peninsula. Geochemistry, Geophysics, Geosystems, 17(12):4920-4954, 2016. doi: 10.1002/2016GC006545.

G. Roberts, N. White, G. Martin-Brandis, and A. Crosby. An uplift history of the Colorado Plateau and its surroundings from inverse modeling of longitudinal river profiles. Tectonics, 31(4):TC4022, 2012. doi: 10.1029/2012TC003107.

G. G. Roberts. Scales of similarity and disparity between drainage networks. Geophysical Research Letters, 46:3781-3790, 2019. doi: 10.1029/2019GL082446. 
G. G. Roberts and N. White. Estimating uplift rate histories from river profiles using African examples. Journal of Geophysical Research: Solid Earth, 115(B2):B02406, 2010. doi: 10.1029/2009JB006692.

E. Rodriguez, C. Morris, J. Belz, E. Chapin, J. Martin, W. Daffer, and S. Hensley. An assessment of the SRTM topographic products. Technical Report JPL D-31639, Jet Propulsion Laboratory, Pasadena, California, 2005.

V. Rodríguez Tribaldos, N. J. White, G. G. Roberts, and M. J. Hoggard. Spatial and temporal uplift history of South America from calibrated drainage analysis. Geochemistry, Geophysics, Geosystems, 18(6):2321-2353, 2017. doi: 10.1002/2017GC006909.

G. H. Roe, D. R. Montgomery, and B. Hallet. Effects of orographic precipitation variations on the concavity of steady-state river profiles. Geology, 30(2):143-146, 2002. doi: 10.1130/00917613(2002)030<0143:EOOPVO $>2.0 . \mathrm{CO} ; 2$.

G. Rosenbaum and G. S. Lister. Neogene and Quaternary rollback evolution of the Tyrrhenian Sea, the Apennines, and the Sicilian Maghrebides. Tectonics, 23(1):TC1013, 2004. doi: 10.1029/2003TC001518.

L. Royden and J. T. Perron. Solutions of the stream power equation and application to the evolution of river longitudinal profiles. Journal of Geophysical Research: Earth Surface, 118(2):497-518, 2013. doi: 10.1002/jgrf.20031.

J. F. Rudge, G. G. Roberts, N. J. White, and C. N. Richardson. Uplift histories of Africa and Australia from linear inverse modeling of drainage inventories. Journal of Geophysical Research: Earth Surface, 120(5):894-914, 2015. doi: 10.1002/2014JF003297.

R. Sartori, G. Carrara, L. Torelli, and N. Zitellini. Neogene evolution of the southwestern Tyrrhenian Sea (Sardinia Basin and western Bathyal plain). Marine Geology, 175(1):47-66, 2001. 
D. Secci, C. Patriche, A. Ursu, and L. Sfîcă. Spatial interpolation of mean annual precipitations in Sardinia. A comparative analysis of several methods. Geographia Technica, 9(1):67-75, 2010.

Servizio dell'Attivià Mineraria, 1959. Bonorva. Servizio dell'Attivià Mineraria, Florence, 1959. 1:100000 Fogli 193.

Servizio dell'Attivià Mineraria, 1988. Саро Мапnu - Macomer. Servizio dell'Attivià Mineraria, Florence, 1988. 1:100000 Fogli 205-206.

L. Sklar and W. E. Dietrich. river longitudinal profiles and bedrock incision models: Stream power and the influence of sediment supply.

F. Speranza, I. Villa, L. Sagnotti, F. Florindo, D. Cosentino, P. Cipollari, and M. Mattei. Age of the Corsica-Sardinia rotation and Liguro-Provençal Basin spreading: new paleomagnetic and Ar/Ar evidence. Tectonophysics, 347(4):231-251, 2002. doi: 10.1016/S0040-1951(02)00031-8.

L. Staisch, R. Blakely, H. Kelsey, R. Styron, and B. Sherrod. Crustal structure and Quaternary acceleration of deformation rates in central Washington revealed by stream profile inversion, potential field geophysics, and structural geology of the Yakima folds. Tectonics, 37(6):1750-1770, 2018. doi: 10.1029/2017TC004916.

G. Stucky de Quay, G. Roberts, J. Watson, and C. Jackson. Incipient mantle plume evolution: Constraints from ancient landscapes buried beneath the North Sea. Geochemistry, Geophysics, Geosystems, 18(3):973-993, 2017. doi: 10.1002/2016GC006769.

G. Stucky de Quay, G. G. Roberts, D. H. Rood, and V. M. Fernandes. Holocene uplift and rapid fluvial erosion of Iceland: A record of post-glacial landscape evolution. Earth and Planetary Science Letters, 505:118-130, 2019. doi: 10.1016/j.eps1.2018.10.026.

S. Vacca, G. F. Capra, E. Coppola, M. Rubino, S. Madrau, A. Colella, A. Langella, and A. Buondonno. From andic non-allophanic to non-andic allophanic Inceptisols on alkaline basalt in 
Mediterranean climate: a toposequence study in the Marghine district (Sardinia, Italy). Geoderma, 151(3-4):157-167, 2009. doi: 10.1016/j.geoderma.2009.03.024.

A. Veldkamp, J. Schoorl, J. Wijbrans, and L. Claessens. Mount Kenya volcanic activity and the Late Cenozoic landscape reorganisation in the upper Tana fluvial system. Geomorphology, 145-146: 19-31, 2012. doi: 10.1016/j.geomorph.2011.10.026.

S. Vingiani, O. Righi, S. Petit, and F. Terribile. Mixed-layer kaolinite-smectite minerals in a red-black soil sequence from basalt in Sardinia (Italy). Clays and Clay Minerals, 52(4):473-483, 2004. doi: 10.1346/CCMN.2004.0520408.

Y. Wang, H. Zhang, D. Zheng, J. Yu, J. Pang, and Y. Ma. Coupling slope-area analysis, integral approach and statistic tests to steady-state bedrock river profile analysis. Earth Surface Dynamics, 5(1):145-160, 2017. doi: 10.5194/esurf-5-145-2017.

K. X. Whipple. Bedrock rivers and the geomorphology of active orogens. Annual Review of Earth and Planetary Science, 32:151-185, 2004. doi: 10.1146/annurev.earth.32.101802.120356.

K. X. Whipple and G. E. Tucker. Dynamics of the stream-power river incision model: Implications for height limits of mountain ranges, landscape response timescales, and research needs. Journal of Geophysical Research: Solid Earth, 104(B8):17661-17674, 1999. doi: 10.1029/1999JB900120.

A. Whittaker, M. Attal, P. Cowie, G. Tucker, and G. Roberts. Decoding temporal and spatial patterns of fault uplift using transient river long profiles. Geomorphology, 100:506-526, 2008. doi: 10.1016/j.geomorph.2008.01.018.

A. C. Whittaker and S. J. Boulton. Tectonic and climatic controls on knickpoint retreat rates and landscape response times. Journal of Geophysical Research: Earth Surface, 117(F2):F02024, 2012. doi: 10.1029/2011JF002157. 
A. C. Whittaker and A. S. Walker. Geomorphic constraints on fault throw rates and linkage times:

889 Examples from the Northern Gulf of Evia, Greece. Journal of Geophysical Research: Earth Surface, 120(1):137-158, 2015. doi: 10.1002/2014JF003318. 